\title{
Do Kinship Networks Strengthen Private Property? Evidence from Rural China
}

\author{
Taisu Zhang \\ Xiaoxue Zhao* \\ February 8, 2014
}

\begin{abstract}
This paper finds that the existence of strong kinship networks tends to limit state interference with private property use in rural China by protecting villagers against unwanted government land takings. It then distinguishes kinship networks from other kinds of social networks by showing that their deterrence effect against coercive takings is far more significant and resilient under conditions of prevalent rural-urban migration than deterrence by neighborhood cooperatives and religious groups. Finally, the paper attempts to identify and differentiate between various possible mechanisms behind these effects: It argues that kinship networks protect private property usage mainly through encouraging social reciprocity between kinsmen, which facilitates collective action against coercive takings. Kinship networks are more effective than neighborhood cooperatives or religious groups at sustaining reciprocity over long distances and, therefore, are less affected by rural-urban migration. Altruism between kinsmen, however, does not emerge from the data as a major factor.
\end{abstract}

JEL Classification: D70, K11, P26, P32

\section{Introduction}

How do kinship networks affect the strength and security of private property, particularly in highly commercialized economies with significant labor mobility? As countries with strong traditions of kinship organization - which describes most of Asia, Latin America and Africa-assume greater importance in the global economy, this has become an increasingly pressing question. Kinship networks in these countries commonly afford, indeed force upon, property owners a series of interpersonal relations and obligations that significantly affect their ability to deter outside interference

*Taisu Zhang is a Visiting Assistant Professor at the Duke University School of Law. Xiaoxue Zhao is a $\mathrm{PhD}$ candidate at the Yale University Department of Economics. Please send any correspondence to zhang@law.duke.edu, or to Taisu Zhang, Duke Univ. School of Law, 210 Science Dr., Room 4011, Durham, NC 27708. For their insightful comments, the authors thank Barak Richman, Robert Ellickson, Nancy Qian, Daria Roithmayr, two anonymous reviewers, and audience members at the American Law and Economics Association Annual Conference and the Duke-UNC Junior Faculty Workshop. The authors are responsible for all remaining errors. 
or encroachment, whether by state or private actors. Whether and why these effects are positive or negative has large ramifications for economic policy-making and property regulation, especially in the developing world.

Several scholars have suggested specifically that kinship networks, like other kinds of social networks, can help shield private property against undesirable government intrusion. To date, however, there has been fairly little empirical verification of that assertion. The few empirical studies that do exist tend to be cross-country comparisons that provoke endogeneity and measurement concerns and, in any case, reach few concrete conclusions. The lack of compelling empirical data has thus far prevented scholars from reliably identifying the actual mechanisms through which social networks protect private property. In addition, these studies usually lump kinship networks with other kinds of social networks, notably neighborhoods and religious organizations, and treat them as functionally similar-despite intuitive reasons to believe that different kinds of networks may have significantly different effects on property institutions.

This paper attempts to fill some of this empirical gap. We examine whether, from 1986 to 2006, the existence of strong kinship networks affected government land takings in 238 rural Chinese villages. These villages, covering 30 of China's 31 provinces-excluding Tibet—were selected for the representativeness of their general socioeconomic conditions. We also compare the property-protecting effects of kinship networks with those of neighborhood organizations and religious groups.

We select rural China as our empirical focus, first, because of the well-documented sociopolitical importance of kinship networks there and, second, because Chinese rural land-use laws during this period allowed local governments to seize land at prices dramatically lower than market value. This created considerable local antagonism towards such takings, which could usually only be executed coercively. Higher frequency and volume - but particularly frequency-of land takings reasonably correlate, therefore, to lower security of property rights against state encroachment.

We find that stronger kinship networks, measured by the prevalence of active lineage genealogies (zupu) and ancestral halls (citang) in a village, strongly correlate with lower levels of land taking, even after controlling for potential endogenous variables such as per capita landholding and proximity to urban centers. Because the danger of reverse causation is low here, we argue that kinship networks protected property rights against unwanted land takings. We also find that China's massive rural-urban migration over the past three decades has eroded the protective effect of kinship networks much less severely than those of neighborhood organizations and religious groups. This argues against lumping these social networks together in generalized theoretical terms.

Finally, we attempt to identify and differentiate some of the specific mechanisms through which kinship networks deter land takings. The existing literature suggests three theoretical possibilities: First, by supplying organizational apparatuses and information-sharing mechanisms, kinship networks encourage collective action against outside encroachment. Second, by sustaining regular social interaction between individuals, both within and between networks, they encourage general reciprocity between them, thereby increasing the social cost of harmful or free-riding behavior and encouraging mutual cooperation, whether between government entities and farmers, or between individual farmers. Third, by creating norms of group solidarity, they potentially promote altruism among members.

Our data demonstrates, first of all, that altruism was probably not a major factor. We find that, all other things being equal, villages with one large kinship network suffer more takings than vil- 
lages with several smaller kinship networks of similar cumulative size. This is quite inconsistent with intra-kinship network altruism being a significant deterring factor against takings. Moreover, while the provision of information-sharing and organizational apparatuses may have been a significant factor, it clearly was not the only significant factor. Other kinds of social networks, particularly neighborhood organizations, can be similarly effective at providing these institutional resources. Consequently, they cannot explain why the protective effects of neighborhood organizations and religious groups were eroded more heavily by migration than those of kinship networks. Rather, we propose that this phenomenon is explained by the fact that kinship networks were more effective than other social networks at sustaining regular social interaction and reciprocity over long distances.

The rest of the paper is organized as follows. Section Two reviews and critiques the relevant academic literature. Section Three surveys land taking procedures and kinship networks in rural China. Section Four lays out our main theoretical arguments. Section Five describes the data and statistical methods. Section Six presents the results. Section Seven concludes.

\section{Literature Review}

Scholars have long believed that the establishment of clear and secure private property rights is necessary for modern economic development (Knack \& Keefer 1995, at 210-11). In particular, most agree that private property-both use and ownership, but especially use-should be protected against coercive and under-compensated intrusion by government entities, and, in fact, that the provision of such protection was a crucial step in the economic takeoff of Western Europe and other developed economies (e.g., North \& Weingast 1989; North \& Thomas 1973). On the other hand, many assert that the lack of such protection continues to hinder economic growth in developing countries (de Soto 2000).

Considering the-important and much-needed-recent back-and-forth between property law scholars on the precise meaning of "property rights" (e.g., Cole \& Grossman 2002), it may be useful to clarify what this "property and development" literature means when it argues for the "protection" of private property against state intrusion: It does not simply argue that governments must respect the express legal boundaries they set for themselves, but rather argues that those legal boundaries must be sufficiently narrow so that actual state interference with property usage - defined broadly to cover all economic activities involving property-is both rare and predictable. In other words, they call not merely for the creation and protection of clear property rights, but also for the creation and protection of clear and substantively private-vis-à-vis statecontrolled-property rights, which allow producers to securely enjoy the fruits of their own labor and investment, freely alienate the property, and use it as collateral (e.g., North \& Weingast 1989; de Soto 2000). They are attempting to define a substantive state-individual relationship, in which individuals are incentivized to use property in what they see as economically productive ways, and not just a procedural or formal one.

If, for example, government expropriation of land is completely conducted within legal boundaries, but is so frequent and coercive that landholders no longer have any incentive to invest in long-term improvements, that would constitute a substantive violation of secure private property use, even if it is not necessarily a legal or procedural one. ${ }^{1}$ In the end, what matters is how much

\footnotetext{
${ }^{1}$ This is, after all, the conventional perceived problem with socialist, state-planned economies. It also helps to
} 
the state can actually interfere with private property usage, not how much it is legally entitled to. Creating clear legal entitlements can certainly strengthen private property in substantive ways, but in some cases that is neither sufficient, or, when local social norms are sufficiently strong and sophisticated and the formal legal system sufficiently weak, even necessary (see, e.g., Ellickson 1991; Ellickson 1993).

Shielding property from state intrusion is, of course, only part of the puzzle. Private property also needs to be shielded from intrusion by non-state actors-in other words, against other people, and perhaps against potentially oppressive social norms. Nonetheless, given the massive expansion of government authority in modern societies, even (and often especially) in developing countries, deterring government intrusion is, at the very least, a necessary and particularly important step in the establishment of substantive private property rights.

These conclusions lead, however, to a crucial follow-up question: How, precisely, should we balance state-society relationships so that private property, where it exists, is substantively secured against undesirable government intrusion? Broadly speaking, scholars have taken two different approaches to this problem: First, many have studied how government institutions can be designed to prevent over-extension of state power-how the state can make, in Douglass North's words, "credible commitments" to respect private property (North 1994). This top-down approach often involves either curtailing the government's overall size and authority, or establishing separation of powers between different branches (e.g., Acemoglu \& Robinson 2012; North \& Weingast 1989).

Alternatively, a less visible but growing collection of studies has explored bottom-up approaches in which non-government institutions are strengthened to combat state intrusion. Most notably, scholars have begun to empirically evaluate whether the existence of organized social networks, sometimes also referred to as "civic groups," "associational activity," or "social embeddedness," helps protect against governmental overreach, including, specifically, governmental interference with private property use through coercive and under-compensated land takings (e.g., Peng 2004; Knack \& Keefer 1997; Licht et al. 2007, at 663-64). These studies fit into a broader academic literature on whether social networks enhance certain aspects of socioeconomic welfare, such as education, interpersonal trust, public works, and insurance against economic shocks (Durlauf and Fafchamps 2004).

This literature supplies three broad theoretical mechanisms through which social networks may conceivably strengthen private property against government intrusion. First, scholars generally agree that social networks encourage group collaboration by facilitating information-sharing and the development of organizational structures (Tsai 2007; Peng 2004, at 1053; Burt 2001, 1992; Coleman 1990, at 270-73). This allows network members to better understand the abilities, obligations and interests of other members, thereby helping them identify when and how collaborative activities are desirable. Networks that provide these institutions respond more coherently and decisively to challenges against recognized norms, both external and internal, and therefore deter against them more effectively. In the land takings context, this means that social networks can help coordinate collective retaliation against encroaching behavior.

Second, insofar as they encourage repeated social interaction, networks help build trust and reciprocity among members (Ellickson 1991; Coleman 1990). By enhancing the threat of retaliation in future rounds, sustenance of repeated interaction discourages harmful behavior and incen-

remember that North and Thomas' classic criticism of Southern European states (1973) was not that they interfered with private property illegally, but that they were legally allowed to interfere too much. 
tivizes cooperation. Intuitively, people are more likely to regularly interact, cooperate, and trust one-another as embedded members of a network than as scattered individuals. In addition, interactions between members of different networks are also more likely to escape prisoner's dilemmas than interaction between completely unconnected individuals: Even if A only interacts once with $\mathrm{B}$, a member of a different network, his incentive to cheat decreases if there is a substantial possibility of future interaction with other members of B's network, or if representatives from his own network interact regularly with representatives from B's network. Therefore, a region that is organized into social groups may enjoy more reciprocity, civic cooperation, and trust both within and across group lines.

This manifests itself in two different ways in land takings. First, social networks may deter against coercive takings if they directly facilitate regular social interaction and reciprocity between the government officials in charge and the targeted landowner. There are multiple scenarios for this: they may belong to the same network, or they may be representatives of two mutually-cooperative networks. In either case, the landowner can individually retaliate against the taking, perhaps by damaging the official's social reputation or, if plausible, issuing material sanctions. Second, social networks facilitate collective retaliation against takings- when there is a collective interest to do so-by deterring against free-riding behavior. As numerous papers have discussed, collective action is difficult to organize because, for the individual, it is often more efficient to "free ride" on the efforts of others-in essence, a multiplayer prisoner's dilemma. Regular social interaction and reciprocity, where they exist, can help solve this problem by punishing free riders and rewarding active participation.

Third, a number of scholars have theorized that altruism within social networks may play an important role in creating and enforcing private property rights (Rose 1990; Krier 1992; Ellickson 1993). A growing number of economists acknowledge that people may behave altruistically towards one another: that is, one's utility may be positively affected by the utility changes of another (Schulze et al. 2003; Hayashi 1995). This definition may be confusing to scholars in other fields, particularly psychology or philosophy, who more commonly define altruism as an individual acting "in the interests of others without the expectation of reward or positive reinforcement in return" (Karra et al. 2006). Regardless of these conceptual differences, however, both sides would agree that people often act in the benefit of others, even when the act conveys no economic, political or social benefit to themselves. For simplicity's sake, we adopt the economic definition of altruism.

Scholars generally agree that social networks often promote altruism among members (Leider et al. 2009). Altruistic behavior is, for example, particularly common and powerful among close relatives (Curry et al. 2012; Alger \& Weibull 2010), and may also develop between friends of all sorts. Greater altruism leads primarily, of course, to more cooperative behavior between members-like repeated interaction, but without the need for actual or threatened future punishment (Ball 2001). In the land takings context, altruism may lead to more cooperative behavior between government officials and members of their own networks. Alternatively, it may encourage people to collectively retaliate against coercive takings inflicted upon members of their network. In fact, it fundamentally lessens, even eliminates, the urge to free ride, as one's utility is directly lowered by any harm to those he cares about (Peng 2004).

As a purely theoretical matter, there may be a fourth or even fifth mechanism through which social networks deter against coercive land taking, but which has thus far escaped academic attention. At the moment, however, the more pressing concern is to better understand the three existing possibilities. 
Our current understanding of the relationship between social networks and property expropriation remains very incomplete. First, some major studies make little theoretical distinction between different kinds of social networks (e.g., Knack \& Keefer 1997; Licht et al. 2007). It seems likely, however, that different kinds of networks do, in fact, function in substantially different ways. On a general level, political economists and sociologists have repeatedly suggested that the socioeconomic effects of families and kinship networks are quite different from those of other social ties and organizations, and should be analyzed separately (e.g., Alesina and Guliano 2010; Bentolilla and Ichino 2008; Gambetta 1990). There is no good reason why that assumption should not also apply to the effects of social networks on intrusive state action: Kinship networks, for example, may inspire stronger altruism than most other kinds of social networks (Curry et al. 2012; Alger and Weibull 2010), and may be more effective at sustaining reciprocity.

More importantly, as demonstrated below, social networks may react to demographic mobility in very different ways. As scholars across multiple disciplines have long observed, the demographic mobility of modern market economies is probably the most important reason why traditional social networks — and the "moral economies" they often create—have tended to disintegrate as market integration intensifies (Greif 2006b; Buoye 2000; Scott 1985; etc.). Neighborhood organizations, for example, are perhaps most susceptible to such disintegration, simply because they require the physical presence of members to function, and therefore usually fail to maintain ties when members move around. Religious groups, too, function best when mobility is low: members who migrate may carry their faith with them, but probably not their social ties to their old congregations. Kinship networks, on the other hand, are theoretically different: relatives who migrate are still relatives. Certainly they will interact less with other members, but probably not to the point where all social reciprocity ceases to exist. Finer differentiation between types of social networks would therefore allow us to better understand their compatibility with modern economic conditions.

Apart from this general theoretical concern, the empirical results obtained in previous studies are also deeply ambiguous and subject to considerable skepticism. Most results are derived from large cross-country comparisons, which have thus far offered few concrete conclusions: Knack and Keefer (1997) argue, for example that, in a survey of over 100 countries, higher levels of "social capital," defined as civic cooperation and trust, led to stronger and more secure private property and better macroeconomic performance. On the other hand, they find no clear evidence that social networks either boost or damage civic trust. (Knack \& Keefer 1997, at 1271-73)

More recent cross-country studies have done little to resolve this ambiguity. Williamson and Kerekes (2010) find that "informal institutions," defined broadly as "culture," do more to strengthen private property than formal legal institutions, but reach no clear conclusion on whether social networks affect "informal institutions" positively or negatively. Licht et al. (2007) find that high levels of social embeddedness actually correlate to more corruption and government intrusion into private life, but provide no empirical measure of how private property and contract relations are actually affected. Their results echo the old theoretical assumption that individualism, not group activity, is the best protector of personal rights and private property (Habermas 2001; Olson 1982).

In any case, by taking entire countries as their empirical unit, these studies naturally provoke concerns about whether they have satisfactorily controlled for the potentially massive amounts of endogenous factors: different levels of economic development, geographical factors, broad cultural paradigms, deep-rooted historical legacies_-particularly the institutional and economic legacies of the British Empire-and so on. One also must wonder if we can truly quantify concepts such 
as "trust," "civic cooperation," and "social embeddedness" at the international level, when the meaning of those concepts, not to mention the meaning of any survey questions used to measure them, vary tremendously depending on cultural and social context. The three studies cited above, at least, measure these sociocultural factors in very different ways, both methodologically and source-wise.

A notable exception to these cross-country studies is the recent work of sociologist Yusheng Peng, who quite uniquely attempts to measure the effect of kinship networks, separated from other social networks, on the security of private property use and business activity (Peng 2004). Utilizing data from several hundred villages in rural China, Peng claims that there is a significant positive correlation between the existence of large kinship networks and secure private property use, which in turn stimulates entrepreneurship.

While this approach—comparing large numbers of localities within the same country-commendably avoids many of the measurement and endogeneity problems that plagued the cross-country studies, the technical execution of Peng's study is very problematic. First, he equates the concentration of villagers under a few large surnames with the existence of strong kinship networks. As discussed below, this is highly questionable, as large surname groups are often only loosely related and poorly organized. Second, and more seriously, he provides no direct measure of property security at all. Instead, he simply demonstrates a correlation between large surname groups and villagelevel entrepreneurship, and then somehow assumes, with no evidence whatsoever, that high levels of entrepreneurship are evidence of secure private property. One can easily imagine any number of circumstances where high levels of business activity instead correlate to ruthless government taking of land, which then stimulates capital aggregation and investment among privileged classes. Third, he controls for very few endogenous factors, overlooking some rather obvious ones, most notably the village's per capita landholding and wealth. Finally, he makes no attempt to identify the specific mechanisms through which kinship affects property security and business.

Despite these problems, we agree with Peng that rural China is a fairly ideal testing ground to study the impact of kinship on private property usage: China has a particularly deep and powerful tradition of kinship. Moreover, its legal and political conditions allow us to easily differentiate villages where private property usage is relatively secure from government expropriation from those where it is not. These conditions are discussed in the following section.

\section{Background Information}

\section{A. Kinship Networks}

Throughout imperial Chinese history, kinship organizations played a major role in organizing all aspects of social, political and economic life-in fact, their importance increased steadily after around $950 \mathrm{AD}$ as large lineages began to emerge and expand among commoners (Li \& Jiang 2000; Inoue 2008). Sponsored by a long series of favorable government policies from around $1000 \mathrm{AD}$ to the early 20th Century, although with some periods of state hostility in-between, lineages and other forms of kinship groups came to assume increasing doses of political power and obligation, often superseding village and even county-level government administrations as the primary unit of socioeconomic regulation and control. Perhaps equally significantly, the intellectual and perhaps religious dominance of Neo-Confucianism, which argued for kinship solidarity and 
ancestor worship with unprecedented rigor, helped promote the moral internalization of kinship norms in much of the population (Inoue 2008, at 87-101).

By the 18th and 19th Centuries, large kinship networks were an almost omnipresent fact of life in all core Chinese provinces, although their size, political authority and economic strength varied from region to region. Even on the North China Plain, however, where kinship networks were smaller and substantially less powerful than elsewhere, a handful of major kinship networks still dominated most villages, occupying the great majority of political appointments (Huang 1985; Pomeranz 1993). Moreover, important social and economic decisions-substantial land-selling, marriages, funerals, and so on-were expected to be made in consultation with senior relatives. In other, wealthier, regions of China, particularly the Lower Yangtze and South China, kinship groups expanded into lineages with significant amounts of corporate property. It was hardly uncommon in these regions for a village to be demographically and politically dominated by one large lineage (Zhang 2006; Huang 1990; Hsiao 1960). In South China, that lineage might also own, as essentially a corporate entity, perhaps a third of the village's land (Pomeranz 2000, at 71-72; Zheng 2000).

Government officials further buttressed the institutional importance of kinship networks by expressly delegating political authority to them. By any measure, the Qing state exercised rather weak control beyond the county level, largely because local government units were seriously understaffed and underfunded (Reed 2000; Ch'u 1962). Consequently, most sub-county socioeconomic regulation and administration were formally delegated to self-governing groups such as guilds, religious groups, and especially kinship networks. Internal lineage regulations on economic transactions were, for example, enforceable in the official court system (Zhang 2012; Huang 1993).

The massive historical upheavals during the 20th and early 21st Centuries have, of course, forced considerable change in the social and political functions of kinship networks (Feng 2005). Most fundamentally, apart from the increasingly clannish behavior of Communist Party oligarchs in high-level politics, kinship organizations have found it difficult to enforce solidarity among members in urban settings. Even in rural China, where they remain highly visible and socially significant, the dramatically increased administrative and regulatory capacities of the Chinese state have inevitably weakened their formal institutional authority. Compared to its predecessors, the modern Communist state has a vastly larger bureaucratic apparatus, and exercises much stronger control over policy and regulation at the township-level or beyond. ${ }^{2}$ Although kinship networks remain highly important within villages, the integration and development of a commercial economy has meant that fewer socioeconomic issues are actually decided at that level. Moreover, unlike in the Qing, the current government does not formally delegate power to kinship group leaders.

Nonetheless, extensive sociological surveying of rural villages during the 1990s and 2000s suggests that kinship networks continue to be a major, perhaps dominant, organizing principle in rural Chinese society (Yang 1999; Bian 1997; Wang 1991). In fact, during periods of social upheaval, for example the Cultural Revolution or, in perhaps a more benign fashion, the economic "opening-up" of the 1980s, villagers tended to re-strengthen local kinship organizations as a selfdefense mechanism (Chan et al. 1992), one that helped coordinate the sharing of resources, of course, but also coordinated action against unwanted external interference, whether from other villages, outlaws, or the local government (Qian 1994). Although state expansion has imposed

\footnotetext{
${ }^{2}$ This was, of course, a contested and often bloody process. See, e.g., Friedman et al. 1991, for an account of one village's political transition during the PRC.
} 
limitations on such self-organizing activity, it remains quite dynamic within those boundaries, and even pushes back against them on occasion.

The basic organizational aspects of Chinese kinship groups have remained fairly stable throughout the past few centuries. Kinship networks are usually patrilineal descent groups that distribute status and authority largely on the basis of generational seniority: elder generations outranked younger ones and, within a generation, elder relatives outranked younger relatives (Ruskola 2012; Alford 1986). Prior to the 19th Century, some lineages in the Lower Yangtze and South China also gave special status to a descent line of firstborn males extending back to the founding ancestor: the founding ancestor's eldest son, the eldest son's eldest son, and so on. This line of eldest sons ("zongzi") enjoyed higher status than other members of their generation, regardless of age (Feng 2005, at 354-56). Today, although social hierarchies within kinship networks are generally less rigid, elder generations still wield considerable authority and influence over younger ones. This does ensure, however, that these networks usually experience significant "status mobility" with the passage of time.

Contemporary kinship networks maintain their solidarity through a variety of ways. Most simply, relatives are socially required to see each other on certain festivals and occasions, spread across the year. Strong kinship networks also engage in collective activities of considerable cost and complexity, most notably the maintenance of an ancestral hall or lineage genealogy (Yang 1999; Wang 1991). Both of these activities, which grew substantially in popularity during the 1990s, require large investments of money and time, in return for greater psychological unity, better sharing of demographic and financial information between relatives, and a stronger signal of status, cohesion and wealth to other kinship networks.

\section{B. Land Takings}

The second condition that makes China an attractive testing ground is the highly coercive nature of its land takings regime. As much recent scholarship has demonstrated, local governments are allowed to expropriate rural land at compensation levels that amount to only a fraction of the land's actual market value. By reselling the taken land at market values, they make tremendous profits that account for increasingly large portions of their budget. This increases, naturally, the incentive to abuse their authority, while also fueling widespread social resentment. Land takings are, therefore, extremely likely to be coercive, which makes their frequency and volume a reasonably accurate negative measure of how secure private property use is against unwanted government intrusion.

Rural land rights have been governed by several different regulatory regimes since the early 1980s (Zhu et al. 2007; Zhu \& Prosterman 2009; Ravallion \& Chen 2004). Chinese rural residents first obtained individual usage rights over arable land in the late 1970s and early 1980s, as part of the "household responsibility systems" promoted by central and provincial governments. While formal "ownership" of land still rested with local village collectives under this arrangement, individual households obtained the exclusive right to till parcels of land and enjoy their produce, subject only to official taxes and fees-in essence, they enjoyed substantively "private" usage rights over the land. These "private" usage rights were, however, very insecure in their initial form: Most were granted for only three years, with no guarantee of renewal, and were theoretically subject to uncompensated reallocation and expropriation.

Usage rights were gradually strengthened through the 1980s. A 1984 policy document expanded the duration of individual usage rights to 15 years, although scholars have questioned 
whether this was truly enforced (Zhu \& Prosterman 2009; Hong 2004). Perhaps more significantly, China issued its Land Management Law (LML) in 1986, giving formal legal structure to private property usage and government takings. The LML allowed "the state," broadly defined, to initiate rural land taking procedures that would covert rural land into "state-owned" property, a process that would also strip the land's previous occupant of his or her usage rights. Although lower-level officials were very often instrumental in proposing and implementing these procedures, they required ultimate approval by authorities at the county level or above. Depending on how the expropriated land was previously classified, approval from the provincial or national government could be necessary. Furthermore, land takings must be for "the public interest," and must give adequate compensation to farmers who were stripped of their usage rights.

Compensation was doled out in two parts: First, the previous landholders were compensated for their loss of usage rights, valued at 3 to 6 times the land's average annual produce ("times annual produce"- “TAP"). Second, they were compensated for resettlement fees, valued at 2 to 3 TAP for each member of household, but capped at 10 TAP. Total compensation would therefore not exceed 16 TAP, but could be as low as 5 to 9 TAP. Government entities that attempted to compress compensation to the lowest permissible level were perfectly within their rights. Once the land had been taken, the government was free to convey it to the highest bidder, usually industrial entrepreneurs or urban-based developers. Bidding would usually happen well before the takings process had concluded, allowing the government to anticipate its financial return from the process (Pils 2005).

The problem, of course, was that the value of taken land to entrepreneurs and developers, who enthusiastically bid for virtually every piece of expropriated farmland made available to them, far outstripped 16 TAP, to say nothing of the far lower sums that farmers were usually paid. Surveys suggest that farmers were, in practice, usually paid significantly less than 10 percent of the land's "full market value" in the bidding process (Guo 2001; Su \& Chan 2005; Zhu et al. 2007). As a matter of law, because farmers were not allowed to alienate their usage rights to non-agricultural producers, they actually had no legal means of obtaining this "full market value." Nonetheless, many believed-not unreasonably, given the well-publicized government debates on this issue-that the legal restrictions against full alienability might be lifted in the near-future and, therefore, that they should hold onto the land until that day. Furthermore, fairly sophisticated black markets for land emerged in many localities during the 1990s, which allowed farmers to illegally sell their usage rights for far higher prices than what the government paid in takings (Ho \& Lin 2003; Chen 2010; Washburn 2011).

But even without these concerns over alienability and "full market value," 5-16 TAP would still fail to capture the full range of damages incurred by the original landholder: For the remainder of his original term of usage, he would lose out on any improvements in the pure agricultural value of that land: technological advancements, higher real produce prices, or both. Such improvements could actually be very substantial, considering the relatively underdeveloped state of Chinese agricultural technology and the dramatic growth of real grain and vegetable prices over the past two decades. The landholder would also lose all or part of his original livelihood, along with the psychological security and social status that conferred. In addition, high levels of inflation in the Chinese economy over the past two decades tended to seriously devalue the compensations as time passed. More generally, land takings and the insecurity they brought often resulted in in distortions of investment decisions and inappropriate allocation of capital, as well as frequent under-utilization of land, thus lowering the economic returns of all local landholders (Prosterman 
2004).

A separate but related complaint was that, although government entities are only supposed to take land "for the public interest," they often, perhaps usually, did so for less honorable purposes. Suspicion towards the government's intent was, of course, exacerbated by the enormous profits that it made in the resale of taken land. Such suspicion was especially severe and widespread when takings were initiated by any government entity beyond the village level, which were seen-fairly-as far less responsive to village-level interests and concerns. As several scholars have argued, the reselling of expropriated land swiftly became the main source of revenue for China's county and township governments during the 1990s and 2000s (Chen 2010; Wen \& Zhu 1996).

Even when the "public interest" claim was at its strongest-when the expropriated land was directly managed by government entities rather than resold to commercial developers, most commonly to build roads and highways-perceived under-compensation was nonetheless extremely widespread (Zhu et al. 2007). In fact, road building projects, which account for near half of rural land takings, often provoked some particularly high-profile protests, due to the larger number of households that they tended to affect (e.g., Chen 2012). Nonetheless, resentment towards takings were, at the individual level, probably greater when the government resold the expropriated land. The problem, of course, is that government entities are indeed particularly enthusiastic about land takings that create large amounts of revenue, which further feeds into the public perception that their intentions are too often dubious (Li \& Vendryes 2012; Yao 2002).

Combined, these factors regularly led to vehement resistance even when the government was willing to pay the upper limit of 16 TAP (Guo 2001; Cai 2003). As a result, rural petitions and riots against land takings ballooned during the 1990s, rapidly becoming one of China's most visible social problems. ${ }^{3}$ The rapid growth of the economy actually exacerbated the problem, as it led to dramatically increasing wealth disparity between the urban and rural sectors. Correspondingly, government profit margins in land takings marched upwards, while compensation to farmers remained largely unchanged. This led, unsurprisingly, to even more unhappiness among rural landholders.

The central government was not blind to this: After over a year of well-publicized preparation and drafting, including the issuance of a State Council directive banning coercive land takings, the government revised the LML in 1998, to reflect the greater market value of land-vis-à-vis their pure agricultural value (Zhu \& Prosterman 2009). Farmers were granted, first of all, 30-years usage rights, up from 15 years. Moreover, takings compensation levels were essentially doubled: "Loss of land" compensation was raised to 6 to 10 TAP, while per-capita resettlement fees were doubled to 4 to 6 TAP. Total resettlement fees were now capped at 20 TAP, meaning that total compensation for a taking ranged between 10 to 30 TAP. The government predictably continued to drive compensation levels as low as possible within this range.

In practice, these higher compensation thresholds did fairly little to bring down the volume of land takings, which continued to rise in the years following the LML revision, in fact quite dramatically (Zhu et al. 2007). This is hardly surprising, as even the new compensation levels paled in comparison to the skyrocketing value of land, driven by booming demand from developers and entrepreneurs. Naturally, the widening gap between compensation and resale value fueled increasing levels of social unrest, as reflected in the skyrocketing volume of related riots and petitions in more recent years.

\footnotetext{
${ }^{3}$ There has been much reporting done on this issue. See, e.g., Yardley 2004; French 2005; Zhao 2005.
} 
Between 1998 and 2007, the government issued a series of legislation and regulations designed to boost the security of rural land usage rights. In 2002, a new Land Contracting Law clarified that rural land could not be taken without compensation, that reallocations were generally impermissible within the 30 year period-barring drastic circumstances such as a natural disaster, and that usage rights were inheritable within their expiration period. A number of follow-up policy directives also demanded that local governments obey existing laws and regulations. Finally, in 2007, the new Property Law characterized rural land-use rights as property rights in rem, and stated that takings compensation must be enough to maintain the farmer's living standards "over the long term." Whether this latter stipulation is enforceable remains to be seen.

Commendable though they may be, none of these reforms addressed the fundamental cause of social hostility towards land takings: Farmers continue to feel that the value of "their land," as reflected in both its resale value to developers and the livelihood it provides to them, is vastly higher than the compensation they generally receive. Of course, from a purely legal point of view, the farmers never "owned" the land, but were only granted agricultural usage rights. Nonetheless, this has hardly stopped them from demanding a larger share of the profits, especially when government entities usually attempt to drive a hard bargain and keep compensation levels well below their potential legal ceiling, and when increasing numbers of farmers have access to black markets where they can "sell" land for far higher returns. A 2005 survey of nearly 2000 households in 17 provinces found that over 70 percent of those affected by takings were "very unhappy" with their compensation packages (Zhu et al. 2007). Meanwhile, both officials and scholars have increasingly recognized takings-related disputes as perhaps the largest source of rural social unrest (Lum 2006).

Social hostility towards takings is further aggravated by a series of procedural issues: First, even within the unconscionably low compensation range stipulated by law, the government rarely consults farmers about their preferred compensation package. The 2005 survey suggests that nearly a third of takings subjects were not notified in advance, and only a fifth were consulted about compensation (Zhu et al. 2007). Second, once the land has been taken, most often coercively, farmers have very little access to legal redress (Pils 2005). Part of this is because government entities simply have almost no procedural obligations and very few substantive ones-only that the taking be for "the public interest" and that compensation not fall below the rather pitiful statutory minimum - and, therefore, have often done nothing illegal even when their actions infuriate the farmers. Another part of the story is, however, undoubtedly that local governments actively threaten and retaliate against attempts to legally appeal takings decisions. Consequently, fewer than 1 percent of farmers surveyed in 2005 filed formal legal challenges against either the taking itself or the compensation levels. Clogging legal remedies, however, has funneled social unhappiness into "extralegal" complaint mechanisms, particularly direct petitions to higher-level administrative bodies. The success rate for such petitions is, however, highly unpredictable, and depends heavily on how much trouble the petitioners can credibly threaten government authorities with-for this reason, mass petitions tend to be much more successful than normal individual petitions (Minzner 2006; Zhang 2009). In other words, these petitions are not formalized decision-making processes conducted by state entities, but are rather fluid, opaque, and often highly contentious bargaining processes between adversarial parties.

All things considered, there is very good reason to believe that the great majority of Chinese farmers subject to takings from the mid-1980s to 2007 disagreed with either the taking itself or the related compensation and, therefore, that most takings were significantly coercive-and severely under-compensated relative to full market value. Correspondingly, all other things being equal, 
fewer takings reasonably indicates here that local property is more secure against unwanted government intrusion. Because it is far easier to obtain statistical data on land takings than to otherwise (attempt to) measure the "security of private property use," the predominantly coercive nature of Chinese land takings actually creates highly desirable research conditions for a study like this. Moreover, because courts and other government institutions offer very little redress for victims of coercive takings, the most important deterrence mechanism at their disposal is, in fact, social pressure applied through organized resistance or personal connections.

\section{Theory}

\section{A. Differentiating Between Social Networks}

We argue here that strong kinship networks tend to deter land takings in rural China and, under current socioeconomic circumstances, do so both more effectively and more consistently than other kinds of social networks. That is, their property protecting effects have suffered less much erosion from outward demographic migration than those of neighborhood organizations and religious groups.

In theory, the existence of both neighborhood organizations and religious groups relies fundamentally on the physical proximity of their members: Neighborhood organizations, by definition, are formed between neighbors. Religious groups share, of course, a faith, but in most cases also a common geographical region: The primary reason why an individual congregates with one group of fellow believers versus another is geographic convenience. If s/he moves to a different area, s/he will simply join a new local congregation. Kinship networks, however, are theoretically formed on the basis of lineage and birth. A cousin is a cousin regardless of how far away he lives. In practice, of course, relatives who live nearby interact far more frequently than those who migrate away, but there is at least an organizational bond that exists regardless of distance.

This bond is particularly significant given the massive waves of rural-urban migration that have swept across China. Despite some evidence that many migrants temporarily returned to their villages following the 2008 Financial Crisis, the number of rural-urban migrant workers-defined as rural residents who work in urban centers-has largely remained above 100 million since 1997, reaching as high as 140 million in 2003. Virtually no village has escaped unscathed. (Chan 2008) Between 15 to 20 percent of rural "residents" therefore reside largely in cities and towns, to say nothing of the many million more who have formally become urban residents. The total percentage of the Chinese population residing in urban areas has grew from roughly 20 percent in 1982 to over 50 percent in 2012, bringing the rural population down from over 800 million to around 675 million. Naturally, this has seriously damaged rural social networks.

Most obviously, migration decreases membership in social networks that are geographically defined. A neighbor who leaves for the city is no longer a neighbor, and a fellow religious believer who leaves will worship with a new group. Decreased membership directly damages the network's sociopolitical clout, especially its bargaining power against external government entities. This is, first of all, a simple numbers game - a group of 100 people carries more social weight than a group of 75-but also reflects the psychological uncertainty among those who stay. They may reasonably choose to afford less respect and cooperation to fellow members who seem likely to emigrate soon, thereby damaging group solidarity and cohesion. 
As discussed above, however, migration may have less devastating effects on social networks that are less reliant on bonds of physical proximity. Although kinship networks experience as much emigration as any other kind of network, the social bonds between relatives do not dissolve upon emigration as entirely as those between neighbors, or even members of the same local religious group. While it may be unrealistic to assume that emigrated relatives will still participate substantively in group activities, they usually do maintain a basic level of contact with other relatives, despite the physical distance: They are often expected to send some of their savings back to close relatives, to call back with some regularity, and to try, at least, to return home for several weeks during Spring Festival. The latter, in particular, sustains a substantial social bond between them and their village of original residency. If and when they return, they may, of course, choose to socialize with old neighbors or fellow religious believers, but those social ties themselves carry no inherent obligation to return. In other words, a migrant with few relatives in his hometown will probably not maintain regular contact, unless s/he has other reasons-unrelated to membership in any social network - to do so.

Our empirical results show that the property protecting effects of kinship networks are much more substantial and resilient under conditions of heavy rural-urban emigration - that is, they are both far more statistically significant across rural China, and deteriorate less when there is heavy migration - than those of neighborhood organizations or religious groups. ${ }^{4}$ This suggests that, consistent with the above deductions, kinship networks are indeed comparatively less affected by migration and the physical distance it creates between members.

\section{B. Differentiating Between Mechanisms}

But what do these results imply about the link between kinship networks and secure private property use? The discussion above identified three mechanisms through which kinship networks may protect private property use against external intrusion. In theory, of course, rural Chinese kinship networks can make use of all three mechanisms: Certainly, the heavily overlapping social lives that kinsmen lead facilitate information sharing, and certainly kinship networks commonly provide a leadership structure and norms of seniority. Moreover, the large batch of ritualistic social interactions that kinship norms commonly demand provide a natural foundation for repeated interaction and social reciprocity between kinsmen. Kinsmen are expected, for example, to visit each other on major holidays, particularly during the Spring Festival, Qingming, Duanwu and Mid-Autumn, and would in any case meet each other regularly at ancestor worship rituals or other collective activities. As discussed above, kinship networks also help organize and regularize interaction with

\footnotetext{
${ }^{4}$ One anonymous review has asked if kinsmen stand to share in the gains of retaining control of land in ways that religious or neighborhood affiliates do not. The basic answer is that the Chinese rural land system gives no preference to extended family members in inheritance or land reallocation issues. If a piece of land is lost to a government taking, no villager except the immediate landholders lose anything in the short run, but over the long run, if those unfortunate landholders have yet to leave the village by the time of the next major reallocation (presumably in 20-30 years, when the previous allocation of usage rights expire), then the total pot of land that will be allocated to all villagers will be slightly diminished. So while other villages could share in the gains of retaining control of land, this gain is unpredictable and usually not very substantial, considering the most land-takings only affect around 1 percent of the village's total land. Moreover, because extended family members are given no special status in reallocations, kinsmen who are not part of one's immediate household have basically the exact same incentives as neighbors, friends, or other social acquaintances. These incentives do not, therefore, explain the empirical discrepancy we observe between different kinds of networks.
} 
other kinship networks and, therefore, provide repeated action-like behavior incentives even for interaction between non-relatives. Finally, in obvious ways, kinship affinity is a potentially major source of pure altruistic behavior.

That said, all three mechanisms also theoretically apply to other kinds of social networks: Neighborhood organizations and religious groups likewise provide strong information-sharing mechanisms and organizational structures. Both encourage regular interaction and reciprocity between members and between different social groups. Both also encourage altruistic behavior, the former by encouraging friendship and "neighborliness," the latter often through direct moral exhortations. It is possible, of course, to argue that different kinds of social networks invoke different mechanisms to different degrees-for example, religious exhortation might generate stronger altruism than "neighborliness," but such degree comparisons are difficult to measure.

The fact that, among these social networks, kinship networks are uniquely effective at deterring land takings under current conditions of rural-urban migration allows us to differentiate, to some extent, between these three mechanisms. It suggests that kinship networks rely significantly on either mechanism two or mechanism three-reciprocity or altruism - to deter against land takings in rural China: Of the three mechanisms, the provision of information-sharing and organizational apparatuses is the only one that does not theoretically benefit-relative to other social networks - from the long-distance social ties that kinship networks are uniquely effective in maintaining. Social reciprocity exists only when interpersonal or inter-group interaction is reasonably predictable and regular. Altruism, too, is commonly thought to be stronger if interaction is more predictable.

In-depth information sharing with other members, on the other hand, is unrealistic while living in remote cities, as is effective contribution to group organization. Regularized contact a few times a year-which is what emigrated relatives usually maintain with their hometown-does little to alleviate these problems, even if it may deter cheating on an individual basis. In short, physical proximity is an irreplaceable precondition for these activities. A 100-member kinship network that experiences 20 percent emigration loses as much capacity here as any other social network under similar conditions. This is not to deny the existence of mechanism one, but simply to point out that, by itself, it cannot explain the migration-resiliency of kinship networks. This implies, therefore, that-barring, for now, the existence of a fourth or fifth large-scale mechanism that has thus far escaped academic attention-either mechanism two or mechanism three is at work.

Differentiating between mechanisms two and three requires a different strategy. As discussed above, social networks help sustain reciprocity both between members of the same network and between representatives of different networks. The latter effect encourages cooperative behavior even between members of different networks: Even if the members themselves rarely interact, any cheating between them will generally draw the intervention of network leaders who do maintain repeated contact. Altruism, on the other hand, usually applies only to members of the same social network. Neither kinship bonds nor neighborliness commonly encourage altruism to outsiders. Religious faith may do so, but that is ultimately a matter of personal conviction, distinct from the social network effects of religious groups.

Therefore, if altruism is indeed one of the major mechanisms through which Chinese kinship networks deter takings, we would expect to see that such deterrence is somewhat stronger when kinship networks are larger and more concentrated. For example, a village with one large kinship network that occupies 80 percent of its population will likely enjoy more aggregate altruism than a similarly-sized village with 4 kinship networks, each occupying 20 percent. In the former village, 
80 percent of residents will, in theory, act somewhat altruistically towards 80 percent of residents, whereas, in the latter village, 80 percent of residents will act somewhat altruistically towards only 20 percent of residents. All other things being equal, the former village should enjoy both a higher capacity for collective action and more altruistic behavior from its political leaders.

It seems intuitively possible that these expectations may be partially offset by weaker personal ties between relatives in a larger kinship network. In other words, an individual is altruistic towards more relatives, but also less altruistic towards individual relatives. This may conceivably be because there is an "upper limit," so to speak, of how much energy and emotional investment a person can devote towards social relations, and therefore engaging in more relations will "dilute" the intensity of each individual relation. ${ }^{5}$ There is, of course, a significant theoretical literature on whether the size of a social network affects its capacity for collective action (e.g., Lake and Huckfeldt 1998; McClurg 2003). Generally speaking, capacity should depend more on the network's organizational characteristics than on its raw size, but under some circumstances, larger size may indeed correlate with a mildly lower likelihood of individual participation in collective activities (Siegel 2009). Even so, the accumulative collective action capacity of larger, fully interconnected, networks with a combination of strong and weak connections-which basically describes the structure of a typical kinship network - are nonetheless substantially higher, in theory, than comparably sized collections of smaller networks ${ }^{6}$. Applied to altruism context discussed above, this still means that villages with one large kinship network will likely have more aggregate altruism than those with several smaller ones.

The results below will show that villages with only one dominant kinship network actually display far higher levels of land takings than those divided among several smaller kinship networks of comparable cumulative size. In fact, the former category has basically the same level of land takings as villages with no significant kinship networks at all. These results are highly inconsistent with "altruism" being a major driving provider of social cooperation and collective action. In addition, we run direct tests of whether village political leaders' kinship affiliation-whether they belong to one of the largest kinship networks in the village-affected the level of land takings. We find no evidence that political leaders' potential good-will towards their own kinsmen decreased the frequency of land takings. All in all, patterns of altruistic behavior do not emerge from our results.

Of course, none of this really explains why a collection of smaller kinship networks is significantly more effective at deterring takings than one unified network. The primary objective here is to use these results to demonstrate the limitations of an "altruism story," not to fully explain the results themselves, which would be a separate, perhaps more complicated, project than the one at hand. One somewhat plausible hypothesis is that, given that there are always some village residents who are not part of any major kinship network, a large, dominant network might attempt to "sacrifice" the landholdings of these unconnected residents in the face of state aggression; whereas such "sacrificing" might be more difficult to coordinate among a collection of smaller networks, potentially because information and bargaining costs prevent effective cross-network negotiation on who to sacrifice. ${ }^{7}$ This raises, however, the question of why similar information and bargaining costs do not seem to arise when these networks are collectively combating state intrusion,

\footnotetext{
${ }^{5}$ This is consistent with the finding, made by several political economists, that strong participation in one kind of social relation tends to diminish the strength of other social ties one may have (Alesina and Guliano 2010).

${ }^{6}$ See, for example, the comparison between "small world" networks and "village networks" in Siegel, 2009

${ }^{7}$ We thank an anonymous reviewer for this suggestion.
} 
but perhaps there are social and psychological differences between coordinating the "selling out" of neighbors and coordinating the protection of private property use. These issues deserve more attention than we can afford in this paper.

\section{Data and Methods}

\section{A. Data}

We use data from two sources. First is the Chinese Ministry of Agriculture's National FixedPoint Survey (NFS), a large-scale-in fact, the largest of its kind-longitudinal rural household survey that began in 1986. It tracks about 23,000 rural households in about 300 villages in all continental Chinese provinces and surveys them each year, with the exception of 1992 and $1994 .^{8}$ A stratified representative and random sampling strategy is adopted in collecting this data, in which a representative sample of counties is first selected from each province based on their geographic topology and per-capita income. The sample covers, in the end, $13.5 \%$ of the 2600 counties in China. One village is then chosen from each selected county, from which a random sample of 50 to 100 households are surveyed, depending on the population share of each county in the province. The sample used by this paper covers a panel of 300 villages in 31 provinces from 1986 to 2008, and provides information on village demographics, household income, land distribution, migration and numerous other variables.

Second, we utilize the Village Democracy Survey (VDS), conducted by Gerard Miquel, Nancy Qian and Yang Yao in 2006 and 2011. The VDS provides retrospective information on the social structure and political reform histories of the same villages covered in the NFS. In particular, the survey provides detailed information on sociopolitical characteristics of the village leaders, the presence of social networks, including traditional kinship groups, in the village, and administrative information on all previous land redistributions and takings. We know of no other large-scale survey that provides this information. In our sample of 246 villages, 238 overlap with our 300village sample of the NFS survey. This 238 -village overlap-covering about $8 \%$ of China's counties-constitutes our main data source.

Most of the main variables in the VDS survey are obtained from village administrative records and, unlike most retrospective data, are therefore not subject to lapses in memory. For information not covered in the records, the survey relies on the collective response of current and former living village leaders and elders, all of whom were present together when the survey took place. The only main variables in our study that rely on these responses are those related to lineage genealogies. Other than that, our main dependent variables (measures of the frequency of land takings) and main independent variables (measures of social networks within the villages) rely on administrative records.

\footnotetext{
${ }^{8}$ No other preexisting survey contains representative samples from all 31 provinces.
} 


\section{B. Descriptive Statistics and Measurement Strategies}

\section{Basic Village Characteristics}

Our objective, as stated above, is to test whether the presence of kinship networks in villages affect the security of private property - in the Chinese context, this refers to the security of the 30year land usage rights that farmers possess - and to differentiate between the various mechanisms through which these effects take place. Specifically, we focus on security against government expropriation, and therefore measure the security of private property use by the number of land takings within the survey's time frame.

Table 1 shows some summary statistics from our sampled villages. The average per-capita land holding in our sample is about $1.46 \mathrm{mu}$ (about 0.24 acres), while the average village has about 430 households and 1700 residents. $52.4 \%$ of sampled villages have experienced at least one land taking between 1987 and 2006, with the frequency of takings increasing sharply in more recent times. The mean number of land takings-per-village comes to about 1 , largely consistent with national administrative data.

\section{The Dependent Variable}

Although the survey only records the number of land takings, and not the volume of each taking, there is good reason to believe that frequency alone is a passable, but not ideal, indicator of how difficult it is for the government to take land in that village. First, most takings are qualitatively similar in volume. A quick calculation based on national administrative data shows that, the average rural land taking in recent years amounts to around 20 mu per village (about 3 acres), or about 1 percent of the average village's total landholding. ${ }^{9}$ Anecdotal evidence suggests, however, that takings below $15 \mathrm{mu}$ per village are very rare, perhaps because they are generally not worth the trouble. ${ }^{10}$ It seems reasonable to assume that the great majority of takings fall between 15 and $25 \mathrm{mu}$ per village. In any given village, the amount of resistance aroused by a 15-mu taking is unlikely to differ substantively from that of a 25 -mu taking.

Second, in terms of generating opposition from villagers, the volume of land taking is of secondary importance compared to the frequency. The extra opposition faced by expanding the taking from $10 \mathrm{mu}$ to $20 \mathrm{mu}$ is likely to be far smaller than the extra opposition of taking 10 mu a second time: Promises that "we will not take land again unless absolutely necessary" will lose credibility, while villagers may become more agitated over what they see as a repeat offense. Multiple takings in a single village is, therefore, a much stronger indicator of weak deterrence than

\footnotetext{
${ }^{9}$ According to the best survey data we have (Zhu et al. 2007), perhaps 10 percent or so of Chinese villages experienced a taking in 2005. There are some 930,000 villages in China. (Thurston 2002) In 2005, the total volume of rural land taking was around 1.9 million mu. (Ding 2006) This averages to about $20 \mathrm{mu}$ taken per affected village. In previous years, both the number of villages affected and the total volume taken were considerably lower, hence the average per-village taking size was roughly comparable.

${ }^{10}$ This is based on personal conversations with village leaders in Tianyuan Village, Zhejiang Province (July 25, 2008) and Xishuinian Village, Hebei Province (June 5, 2002), as part of a Peking University sociological research team led by Yang Shanhua and Cheng Weimin. While the circumstances varied from village to village- the Xishuinian village chief stated that he knew of no taking in nearby villages that went below $15 \mathrm{mu}$, whereas the Tianyuan village chief could recall one taking of $12 \mathrm{mu}$ in a neighboring village (an "outlier," according to him) - 8 of 11 land takings that we encountered in our interviews fell into the 15-25 mu range. Apart from the $12 \mathrm{mu}$ taking near Tianyuan, there were two larger takings of 40 and $50 \mathrm{mu}$, respectively, around Xishuinian.
} 
one taking of a larger volume. All in all, the survey's frequency data provide a serviceable measure of security against government intrusion.

\section{Independent Variables}

To measure the presence of kinship networks, we combine information from several independent measures. One commonly-employed predictor of kinship networks is the presence of a large surname that covers a substantial share of the village population. (Peng 2004) In our sample, the median number of surnames in a village is 19 , the median population share of the two largest surnames is $30 \%$ and $16 \%$, respectively, and the median for the total population share of the four largest surname is $78.3 \%$. However, the mere existence of large surnames is no guarantee that people who shared a surname actually engaged in substantive kinship bonding-North China, for example, has historically been festered with counterexamples. (Pomeranz 1993) Instead, we use two other, more accurate, indicators to evaluate the presence and strength of kinship networks: whether active ancestral halls exist, and whether surnames maintain lineage genealogies.

The 2011 VDS records provides these indicators, as well as the population share for each of the four largest surnames in all villages. In addition, the 2006 VDS records the total number of ancestral halls and the total lineage genealogies, including those for the four largest surnames in the village. Based on the information collected from both rounds of the VDS, $17.3 \%$ of the villages have at least one ancestral hall, and in $77.8 \%$ of those villages, the largest surname possessed one of these halls. At the same time, $42.3 \%$ of the villages have at least one surname that maintains a genealogy of the extended family - the average number of lineage genealogies in a village is actually 2.31. Among the four largest surnames in each village, 35.7\% are bound by strong kinship ties (defined as having at least one of the kinship indicator dummies equal to one), bringing the population share of kinship networks to $33.3 \%$ on average.

The paper's main independent variable, kinship1, which is a dummy for the existence of organized kinship networks in the village, incorporates information from all these indicators. In particular, a village is recorded as having significant kinship networks (i.e., kinship1=1), if either the population share of kinship networks among the four largest surnames (as defined above) is greater than $50 \%$ of the entire village, or if the proportion of surnames having either an ancestral hall or a lineage genealogy is above the 85 th percentile of that measure among all villages. ${ }^{11}$ This represents a significant improvement over some previous attempts to identify the presence of strong kinship networks, in that it only captures villages in which a significant share of residents actually engage in collective kinship-based activity.

Villages that have kinship 1=1 can be further separated into two different categories: first, those dominated by one well-organized kinship network, and second, those that have relatively dispersed kinship networks. In order to differentiate between these two categories, the paper further separates all kinship1=1 villages into two subsamples and creates two other kinship measures. Kinship2 is a dummy indicating not only kinship1=1, but also that only one of the four largest surnames

\footnotetext{
${ }^{11}$ The 85th percentile cutoff line captures virtually all villages that have at least one ancestral hall (the median village in our sample has none), and also villages in which over 37.5 percent of surnames-largely correlating to over half the village population-have a lineage genealogy. We chose this cutoff line to capture villages with ancestral halls, and then applied the same line to lineage genealogies, mainly for the sake of simplicity and consistency, but also because it does capture the great majority of villages where over half the population has a lineage genealogy. Overall, 43.9 percent of villages in our sample have at least one lineage genealogy.
} 
is organized into a tight kinship network (as defined above), or if the total number of ancestral halls in the village is one. Because kinship1=1 already requires that the population share or the percentage of surnames with strong kinship ties reach a fairly high level, a village can only have kinship2=1 if the village has a very high surname concentration and the dominant surname in the village is organized under strong kinship ties. Kinship3 is a dummy that incorporates all other villages that have kinship1=1. Creating these two measures allows us to examine whether large and concentrated kinship networks affect land takings differently than smaller, more fragmented kinship networks. Within our sample, $48.0 \%$ of villages are kinship1 villages, with $8.2 \%$ and $39.8 \%$ falling respectively into the kinship2 and kinship3 categories.

We also measure the presence of other networks in the village. The presence of either Buddhist, Catholic, or Islamic religious groups is indicated by a dummy that equals 1 if the population share of that particular religious group is above the 85 th percentile among all villages -95 th percentile for Islam, due to the relatively low number of villages with a Muslim community. The presence of strong neighborhood organizations is indicated by a dummy that equals 1 when there are irrigation cooperatives in the village. These cooperatives are generally formed between farmers with adjacent plots, and allow the pooling of monetary and human resources to construct larger scale irrigation works. They rely, therefore, on both close socioeconomic ties and physical proximity, in basically the same way that strong neighborhood organizations do.

We use the presence of a temple in the village as a separate social network dummy. This is conceptually distinct from - if practically connected to - the religious group dummies. Traditional Chinese folk religion involves a blend of Confucianism, Daoism, Buddhism, and local cults. While village temples may be more or less oriented towards a specific set of ritualistic practices, they are rarely restricted to any one religion, and do not exclude villagers based on religious belief. They also host a wide range of predominantly secular activities-local festivals during secular holidays, opera performances, and movie showings, for example. (Tsai 2007) In practice, then, temples generally indicate a mixture of religious organization and secular bonding between neighbors. At the very least, their existence suggests the existence of voluntary social organizations at work within the village. They are, however, generally unrelated to kinship networks, which conduct their business in separate venues such as ancestral halls.

All social network indicators used in this paper are based on one-time information collected in the 2006 or 2011 VDS survey. We assume, therefore, that these networks, as part of the village's sociocultural and historical legacy, are developed over the long run and thus relatively constant between 1986 to 2006 (or 2011). At least, we assume that their existence is relatively time-invariant compared to other variables we examine, such as village election outcomes and local labor allocation. In China, the household registration system makes permanent migration relatively difficult. As a result, cross-village mobility is low, and the lineage structure within a village usually experiences little change over time. A comparison of the two rounds of the VDS survey shows that among the 249-village sample used in the paper, only in two of them are the largest two surnames in 2006 no longer among the four largest surnames in 2011. Miquel et al. (2012), using both the VDS survey and the National Gazetteer of the Qing Dynasty for 1820, find high correlation between the presence of an in-use temple in a village in 2006 and the presence of a historical temple in the same county in 1820 , lending support to our assumption that social networks are long-term outcomes. 


\section{Empirical Strategy}

In order to measure whether, and to what extent, kinship networks protect villagers against coercive land takings, we run the following regression:

$$
y_{i}=\beta_{0}+\beta_{1} \text { kinship }_{i}+\gamma X_{i}+\varepsilon_{i}
$$

Here, $y_{i}$ is the number of land takings in village $\mathrm{i}$, and kinship $_{i}$, as discussed above, is a measure of kinship networks in that same village. $\beta_{1}$ measures the effect of organized kinship networks on the frequency of land takings. If kinship networks effectively protect villagers against coercive takings, we should find $\beta_{1}$ to be negative.

Theoretically, the level of land takings may be correlated with kinship networks even when there is no causality relation between the two. For instance, kinship ties may be weaker in villages that are closer to urban centers, where the greater availability of outside economic opportunities allows villagers to be less reliant on local relatives. At the same time, land takings may occur more frequently in these villages, due to the higher commercial value of land-compared, especially, to its agricultural value. Similarly, better education for the village labor force theoretically provides villagers with better outside employment options, therefore weakening intra-village kinship ties, while also lowering the relative agricultural value of village land, and therefore reducing the costs of land takings.

In order to eliminate such endogeneity, the paper controls for a group of village characteristics, $X_{i}$, that could potentially be correlated with both kinship networks and land taking frequencies. Specifically, $X_{i}$ includes dummies of whether the village is located in a city suburb or a mining area, the village's geographic typology type, the main crop cultivated in the village, the distance from the nearest main road, the number of households, the per capita net income, the village government's annual revenue, and the average education level of the village labor force. We also conduct other robustness tests for this regression, including controlling for province fixed-effects and the presence of other social networks.

Another potential concern is reverse causality: whether villagers endogenously form or dissolve social networks in response to land takings. The most likely scenario here, however, is that land takings, by increasing the incentive for collective action, would in fact strengthen intra-village social networks. This would actually bias our results positively. In other words, any negative correlation between kinship networks and land takings is unlikely to be the result of reverse causation.

We also test, by running the following regressions, whether the negative effect of kinship networks on land takings is due to village officials' greater-conceivably altruistic-concern for the interests of their own kinsmen. This may conceivably happen when a large share of land takings are initiated by village officials, rather than higher authorities, and, furthermore, when these officials find it either efficient or necessary to target their own kinsmen:

$$
y_{i t}=\begin{gathered}
\beta_{0}+\beta_{1} 1 \text { stVH }_{i t}+\beta_{2} 1 \text { stkin }_{i}+\beta_{3} \text { otherkin }_{i} \\
+\beta_{4} 1 \text { stVH }
\end{gathered}
$$

Regression (2) focuses only on the largest surname in the village. $y_{i t}$ is the dummy of whether land takings occurred in village $\mathrm{i}$ in year t. $1 s t V H_{i t}$ is a dummy indicating whether the village leader at year $t$ belongs to the largest surname of village $i$. 1 st kin $_{i}$ is a dummy indicating whether the largest surname in village $i$ has strong kinship ties- that is, has an ancestral hall or lineage 
genealogy — and otherkin $i$ is a dummy indicating the existence of significant kinship networks in the village despite the absence of strong kinship ties in the largest surname.

If kinship networks deter against land takings largely because village officials desire to keep their own kinsmen happy, then we should expect such deterrence to be stronger in years where village officials belong to one of the village's kinship networks, and weaker otherwise. Conversely, if the largest surname of village $i$ is organized into a kinship network, we should expect the village leaders of that surname to expropriate land less frequently compared to other village leaders in the same village, after we control for the presence of other kinship groups and their differential effect on village leaders from different surnames. Similarly, we should expect village leaders from other surnames to expropriate less compared to village officials from the largest surname, if the largest surname is not organized into a kinship network, but other surnames are. Thus, $\beta_{4}$, which measures the difference (after controlling for otherkin $i$ and 1 st $V H_{i t} *$ otherkin $_{i}$ ) between the negative effect of $1 \operatorname{stkin}_{i}$ on land taking frequency in village-years where village officials belonged to the largest surname and the negative effect of 1 stkin $_{i}$ in other village-years, should be negative. Similarly, $\beta_{5}$, which measures the difference (after controlling for $1 \operatorname{stkin}_{i}$ and $1 s t V H_{i t} * 1 s t k i n_{i}$ ) between the negative effect of otherkin $_{i}$ on land taking frequency in village-years where village officials belonged to the largest surname and the negative effect of otherkin $i$ in other village-years, should be positive. We then use the same empirical strategy to run a similar regression for the second largest surname in the village.

$$
y_{i t}=\beta_{0}+\beta_{1} \text { Ownkin }_{i t}+\beta_{2} \text { Otherkin }_{i t}+\varepsilon_{i t}
$$

Regression (3) expands this analysis to cover the four largest surnames in the village, and tests whether the village leader belonging to any major kinship network affects his land taking behavior. Again, $y_{i t}$ is the dummy of whether land takings occurred in village i in year t. Ownkin ${ }_{i t}$ is a dummy indicating whether the village leader's surname, if one of the four largest surnames in the village, is organized into a kinship network. Otherkin $n_{i t}$ is a dummy indicating that the village possesses strong kinship networks (i.e., kinship1=1), despite the fact that the village leader's own surname is not one of them. Because we only have data on surname-specific kinship behavior for the four largest surnames in each village, we will restrict this regression to village-years where the village leader belongs to one of them. If kinship networks deter land takings mainly because of village officials' goodwill towards their own kinsmen, we should expect Ownkin $_{i t}$ to have a larger negative effect on land takings than Otherkin $_{i t}$ - that is, $\beta_{1}$ should be negative and smaller than $\beta_{2}$.

In order to illustrate how kinship networks may differ from other types of social networks-more specifically, how kinship networks may be less vulnerable to the undermining effects of demographic mobility, the paper runs the following regression:

$$
\begin{array}{r}
y_{i}=\beta_{0}+\beta_{1} \text { kinship }_{i}+\beta_{2} \text { othernetwork }_{i}+\beta_{3} \text { kinship }_{i} * \text { migration }_{i}+ \\
\beta_{4} \text { othernetwork }_{i} * \text { migration }_{i}+\beta_{5} \text { migration }_{i}+\gamma X_{i}+\varepsilon_{i}
\end{array}
$$

Again, $y_{i}$ is the number of land takings in village $\mathrm{i}$, and kinship $p_{i}$, as discussed above, is a measure of kinship networks in that same village. Here, we attempt to capture both the effect of kinship networks and the effect of another network-measured either by the neighborhood organization dummy or the religious group dummy discussed above-on land taking through $\beta_{1}$ and $\beta_{2}$. If both are negative, we then look to the interaction terms between the average percentage of village 
residents who are migrant workers and these network dummies, in order to estimate how much migration impacts their deterrence effect against land takings. If higher levels of migration undermine deterrence, we should expect the coefficients on the interaction terms, $\beta_{3}$ and $\beta_{4}$ to be positive. Finally, if kinship networks are indeed less susceptible to such undermining, we should expect $\beta_{3}$ to be numerically lower that $\beta_{4}$. The same list of village controls, $X_{i}$, as in equation (1) is added to eliminate possible endogeneity.

\section{Results}

\section{A. Main Results}

Table 2 shows the results from regression (1), in which we test the effects of kinship networks on the village-specific land taking risks. In all columns, the dependent variable is the number of land takings that have occurred in our sample period, and we have controlled $X_{i}$, our bundle of village characteristic controls.

In column (1) and (2), we regress the number of land takings against dummies of whether ancestral halls and lineage genealogies exist in the village as well as the against the population share of kinship networks that are among the four largest surnames. Compared to column (1), column (2) adds in province fixed effects as additional controls. As we can observe from the results in both columns. The presence of both ancestral halls and family trees seem to negatively affect the frequency of land takings, and conditional on their presence, the higher the population share of large kinship networks, the lower the village's land taking risk.

Column (3) to (6) show our main results when we regress the number of land takings against kinship1, our primary kinship measure. As shown in column (3), the presence of significant kinship networks has a negative and significant effect on the number of land takings. To further eliminate endogeneity, we add in province fixed effects in column (4). Columns (5) and (6) repeat the regressions in columns (3) and (4), but add in additional controls for the dummies for all other observed social networks - neighborhood organizations, temples, and Catholic, Buddhist and Islamic religious groups - to eliminate any endogeneity due to correlation between kinship networks and other social networks in the village. In all columns, the coefficient of kinship1 remains positive and significant, and actually increases in magnitude from column (3) to column (4). All in all, these results clearly indicate that the presence of significant kinship networks tend to decrease the number of land takings.

\section{B. Concentrated vs. Scattered Kinship Networks}

To further examine whether large, concentrated kinship networks affect land takings to a substantially different degree than smaller and more diverse kinship networks-which, as discussed above, is a key step in identifying the potential effect of altruistic behavior-we repeat the same regression in columns (5) to (8) of Table 2 on kinship2 and kinship3. The results are presented in Table 3. While the effects of kinship3 on land takings remain significantly negative and similar in magnitude to the effects of kinship1, the coefficients on kinship2 are not significantly different from zero. This suggests that kinship networks exert very weak effects on land takings when only 
one kinship network dominates the entire village. Instead, the protective effect of kinship networks exists only when several kinship networks of somewhat smaller size cohabitate the village.

For robustness, the paper has also repeated all regressions in Table 2 and Table 3 using a Tobit model. The results, which are not shown here, remain the same.

\section{The Role of Village Officials}

We then examine whether, and to what extent, the property-protecting effects of kinship networks were generated by village officials behaving cooperatively, perhaps altruistically, towards their own kinsmen. Table 4 shows the results of regression (2), in which we focus on the behavior of village leaders from the largest surname in the villages. In all columns, the dependent variable is a dummy of whether a land taking occurs in a particular year, and all standard errors are clustered at the village level to observe correlated errors of the same village across different years. We first run a baseline model of the regression in column (1) without any controls. Column (2) then adds in village fixed effects, while column (3) controls for both village and year fixed effects. Columns (4) to (6) repeat the regressions in columns (1) to (3) with the addition of $X_{i t}$. $X_{i t}$ includes the same set of variables that we include in regression (1) as controls, except that now the observations of each variable are at the village-year level. In other words, $X_{i t}$ includes dummies of whether the village is located in a city suburb or a mining area, the village's geographic typology type, the main crop cultivated in the village, the distance from the nearest main road, the number of households, the per capita net income, the village government's annual revenue, and the average education level of the village labor force.

Contrary to what we would expect if cooperative behavior by village officials towards their kinsmen was a major protective factor, $\beta_{4}$, the coefficient of the interaction term between the dummy of the largest surname having kinship ties and the dummy of the village leader belonging to largest village surname, is not negative. Nor is $\beta_{5}$, the coefficient of the interaction term between the dummy of other surnames having kinship ties and the dummy of the village chief belonging to the largest surname, positive. Both interaction effects are statistically indistinguishable from zero, implying that village leaders are not less likely to expropriate land when they belong to a large kinship network.

We then repeat this regression, but replace the largest surname in the village with the second largest surname. The results are presented in Table 5. Although we do have a significant and negative $\beta_{4}$ this time in columns (2) and (3), the estimation does not remain robust once additional controls are added, and becomes indistinguishable from zero in columns (4) to (6). Moreover, we notice that $\beta_{5}$ is in fact more negative than $\beta_{4}$, and remains significant in all columns. There is, therefore, no sign that village officials favored their own kinsmen. If anything, the results seem to suggest that village officials from the second largest surname behave more responsibly when the village possesses significant kinship networks, but they do not personally belong to any of them.

Table 6 presents the results of regression (3), in which we expand the analysis to cover the four largest surnames in the village. Column (1) of Table 6 runs a baseline model of regression (3) without any controls. Column (2) adds in village fixed effects, while column (3) controls for both village and year fixed effects. Columns (4) to (6) repeat the regressions in columns (1) to (3) with the addition of $X_{i t}$, the set of additional controls mentioned in the first paragraph of this section. Here, too, the village leader belonging to a major kinship network has no significant negative effect on land taking frequency. In fact, in all columns except for the first, the difference between $\beta_{1}$, 
the coefficient of whether the village leader's own surname is organized into a kinship network, and $\beta_{2}$, the coefficient of the presence of other kinship networks in the village, is positive. This suggests that other kinship networks actually had a greater deterrence effect on the village leader's land takings decisions than his own kinship network.

\section{Searching for Altruism}

Collectively, these results allow us to narrow down the potential mechanisms through which kinship networks deterred against coercive land takings. The existing theoretical literature identifies, as discussed above, three major possibilities: decreasing information and organization costs, encouraging regular social interaction and reciprocity, and boosting altruism. Our results suggest that altruism played no significant role: There are two kinds of altruism potentially at play in the land takings context - altruism between village officials and landholders, and altruism between landholders. The former is categorically ruled out by the results in Table 4, 5, and 6, which show that cooperative behavior by village officials towards their kinsmen did not deter against land takings. In fact, the fact that other kinship networks actually had a greater deterrence effect on the village leader's land takings decisions than his own kinship network strongly suggest that the political behavior of village elites was driven primarily by pragmatic considerations of cost and benefit, rather than by altruism. The latter, for reasons explained in Section 4.2, is inconsistent with the fact that kinship3's coefficient in regression 2 is significantly negative, whereas kinship2's coefficient is effectively zero: if altruism did play a significant role, villages with one dominant kinship network should not have fared so poorly.

We are left, then, with two possible mechanisms: First, kinship networks may supply informationsharing and organizational institutions, which help victimized landholders identify and organize potential allies for collective retaliation against coercive takings. Second, kinship networks may facilitate regular social interaction — both within and across network boundaries - which then generates higher levels of reciprocity and cooperation both between individual landholders and between local officials and landholders.

\section{E. Reciprocity and Migration}

We cannot rule out either of these mechanisms. We do, however, provide evidence suggesting that mechanism two was particularly significant and, indeed, best explains why kinship networks are substantially different from other kinds of social networks. We demonstrate that, compared to other kinds of social networks, the property protecting effects of kinship networks are not only much more significant, but also less vulnerable to erosion by outward demographic migration. As discussed in Section Four, this provides indirect proof that mechanism two was especially important: Given that altruism did not seem to play a major role, sustaining reciprocity is the only mechanism that can explain why rural-urban migration, which is the dominant demographic and social challenge facing nearly all Chinese village-level social networks, affects kinship networks less severely. If the sharing of information and organizational resources was the only, or even the dominant, mechanism at work, then kinship networks should theoretically have been affected to a similar extent as religious groups and neighborhood organizations.

We first examine whether the existence of other social networks, including Christian, Buddhist, and Islamic religious groups, village temples, and neighborhood-based organizations, deter land 
takings. To do this, we repeat regression (1), as shown in columns (3) to (6) of Table 2, but replace our kinship measure with dummies for these other social networks. In results not shown in this paper, no other social network has a significant main coefficient in their respective regression. This result alone suggests that, under China's current socioeconomic circumstances-dramatic economic growth and rapid urbanization driven by massive rural-urban migration-kinship networks have become the most important, perhaps only, source of collective organization and mobilization in rural China.

Table 7 presents the results of regression (4), in which we compare the effects of migration on kinship networks with its effects on other social networks. In these comparative regressions, only two other social networks have a negative main coefficient $\beta_{2}$, which measures, in this regression, the effect of these social networks on land takings in the absence of interference by kinship networks or significant migration. These are neighborhood-based organizations (organizations of physically proximate households), measured by a dummy indicating the presence of an irrigation cooperative, and Islamic groups, measured by a dummy indicating that the population share of Muslims in the village is above the 95th percentile of all villages. Neither of the negative main effects are statistically significant, whereas the effects of kinship networks $\left(\beta_{1}\right)$ are, as in previous regressions, negative and significant. That said, neighborhood organizations do consistently have negative coefficients even after we add additional controls and province fixed-effects. For the sake of thoroughness, we present the regression results of (4) for both.

In each column of Table 7, we compare kinship networks with one other network: neighborhood organizations in columns (1) to (3), and Islamic groups in columns (4) to (6). We regress the number of land takings over kinship1, the dummy for the comparative network, the percent of village laborers who are migrant workers, and the interaction terms between migration and the two compared network dummies. Columns (1) and (4) show the results of a baseline model where no controls are added. Columns (2) and (5) add in the aforementioned collection of village controls, $X_{i}$. Finally, columns (3) and (6) add province fixed effects on top of the village controls.

As we can see in $\beta_{3}-\beta_{4}$, regardless of which comparative network one chooses, once any control variable is added, the coefficient of the interaction term between kinshipl and migration levels $\left(\beta_{3}\right)$ is consistently lower than the coefficient of the interaction term between the comparative network dummy and migration levels $\left(\beta_{4}\right)$. In addition, in all columns, $\beta_{3}$ and $\beta_{4}$ are positive. These results indicate, first of all, that migration does indeed erode the collective action benefits of social networks. More importantly, they suggest that, compared to other social networks, the deterrence effect of kinship networks on land takings is generally less likely to diminish under conditions of migration. This supports our hypothesis that kinship networks are more effective at sustaining intra-network social reciprocity over long distances and, therefore, are eroded less severely by migration. These results remain robust after the addition of all village controls and province fixed-effects.

\section{Conclusion}

Our results demonstrate, ultimately, that kinship networks do indeed deter against land takings in rural China and, in fact, do so much more resiliently under large-scale external migration than neighborhood or religion-based networks. They also suggest that this deterrence effect probably had little to do with altruism between kinsmen, but much to do with the maintenance of social 
reciprocity, both between kinsmen and between different kinship networks. These are, we believe, more reliable empirical conclusions than those drawn from the cross-nation comparisons in preexisting studies.

There are, of course, a number of limitations to our analysis. First, it goes only as far as our data can take it: the surveys we utilize are the best available, but we nonetheless leave open the possibility that superior surveying in the future may substantively update our findings. Second, we have thus far avoided the issue of whether a case study of China is indeed theoretically representative. There is little in the above analysis that is strongly country specific - the way kinship networks operate in China, at least for our purposes, is not intuitively different from how they operate in other countries, nor is the observation that kinship ties are eroded less by migration than social ties based on physical proximity. Nonetheless, we welcome similar studies of other regions or time-periods. We do believe that a collection of such studies would shed more light on the relationship between kinship and property than broad cross-nation comparisons. China, given its size and growing global influence, is a good place to start.

Finally, this paper has only considered the relationship between kinship networks and state intrusion into private property use. It leaves open the question of whether, and how, kinship networks affect property intrusion by non-state actors, and, therefore, falls short of comprehensively assessing the impact of kinship networks on property security. Given that kinship networks seem to substantially boost social reciprocity and cooperation, we find it highly unlikely that they would somehow encourage intrusion by private parties-especially when almost no one would deny that the predominant form of land usage in rural China is now private and exclusive. In fact, it seems far more likely that they would actually deter such intrusion. Nonetheless, the empirical data presented here neither support nor undermine any of these hypotheses, and we reserve them for future research. 
Table 1: Descriptive Statistics

\begin{tabular}{cccc}
\hline \hline Variable & Obs. & Mean & Std. Dev. \\
\hline No. of land takings & 244 & 0.988 & 1.13 \\
Dummy for at least 1 taking & 244 & 0.525 & 0.499 \\
Kinship1 & 244 & 0.480 & 0.501 \\
Kinship2 & 244 & 0.0820 & 0.275 \\
Kinship3 & 244 & 0.398 & 0.490 \\
Dummy for Islamic groups & 238 & 0.0473 & 0.187 \\
Dummy for neighborhood & 244 & 0.164 & 0.371 \\
Largest surname population share & 237 & 35.8 & 22.9 \\
2nd largest surname population share & 231 & 16.6 & 8.72 \\
Village leader from 2 largest surnames & 5605 & 0.332 & 0.471 \\
No. of households & 5605 & 0.528 & 0.499 \\
No. of residents & 4145 & 424.4 & 288.2 \\
Per capita land (mu) & 4147 & 1664.1 & 1087.2 \\
$\%$ migrant workers & 4132 & 1.69 & 1.81 \\
\hline
\end{tabular}

Notes: Data come from China's National Fixed-point Survey and the Village Democracy Survey. An observation is a village-year for the last six rows and a village for all other rows. The sample covers 1986-2008 for the last 4 rows and 1980-2008 for the two rows immediately preceding them.

Table 2: Effects of Kinship Networks on Land Expropriations

\begin{tabular}{|c|c|c|c|c|c|c|}
\hline & \multicolumn{6}{|c|}{ Dep. Var: No. of Land Expropriations } \\
\hline & (1) & (2) & (3) & (4) & (5) & (6) \\
\hline Ancestral hall & $\begin{array}{l}-0.186 \\
(0.246)\end{array}$ & $\begin{array}{l}-0.105 \\
(0.274)\end{array}$ & & & & \\
\hline Family tree & $\begin{array}{l}-0.117 \\
(0.185)\end{array}$ & $\begin{array}{l}-0.263 \\
(0.200)\end{array}$ & & & & \\
\hline Kinship population share & $\begin{array}{l}-0.170 \\
(0.253)\end{array}$ & $\begin{array}{l}-0.173 \\
(0.285)\end{array}$ & & & & \\
\hline Kinship1 & & & $\begin{array}{l}-0.320^{*} \\
(0.167)\end{array}$ & $\begin{array}{l}-0.342 * \\
(0.192)\end{array}$ & $\begin{array}{c}-0.307 * \\
(0.171)\end{array}$ & $\begin{array}{c}-0.373^{*} \\
(0.194)\end{array}$ \\
\hline Province FE & & & & yes & & yes \\
\hline Other networks & & & & & yes & yes \\
\hline Observations & 212 & 212 & 214 & 214 & 214 & 214 \\
\hline$R^{2}$ & 0.301 & 0.413 & 0.294 & 0.411 & 0.309 & 0.469 \\
\hline $\begin{array}{l}\text { Notes: Data come from } \\
\text { Survey. An observation } \\
\text { of land takings in the vil } \\
\text { (See Section V.C for the } \\
\text { in parentheses. }\end{array}$ & $\begin{array}{l}\text { a's Nat } \\
\text { village. } \\
\text { The st } \\
\text { of varia }\end{array}$ & $\begin{array}{l}\text { al Fixe } \\
\text { all colı } \\
\text { lard se } \\
\text { s) Coe } \\
\text { denote }\end{array}$ & $\begin{array}{l}\text { oint Sur } \\
\text { ss, the de } \\
\text { controls }\end{array}$ & $\begin{array}{l}y \text { and th } \\
\text { endent } \mathrm{v} \\
X_{i} \text {, is con }\end{array}$ & $\begin{array}{l}\text { illage Do } \\
\text { ble is th } \\
\text { lled in al }\end{array}$ & $\begin{array}{l}\text { nocracy } \\
\text { number } \\
\text { columns. } \\
\text { errors } \\
\text { level. }\end{array}$ \\
\hline
\end{tabular}


Table 3: Concentrated vs. Scattered Kinship Networks

\begin{tabular}{lcccc}
\hline \hline & \multicolumn{4}{c}{ Dep. Var: No. of Land Expropriations } \\
\cline { 2 - 5 } & $(1)$ & $(2)$ & $(3)$ & $(4)$ \\
\hline Kinship2 & -0.226 & -0.264 & -0.237 & -0.251 \\
& $(0.278)$ & $(0.311)$ & $(0.284)$ & $(0.308)$ \\
Kinship3 & $-0.345^{*}$ & $-0.359^{*}$ & $-0.326^{*}$ & $-0.401^{* *}$ \\
& $(0.177)$ & $(0.201)$ & $(0.182)$ & $(0.202)$ \\
Province FE & & yes & & yes \\
Other networks & & & yes & yes \\
\hline Observations & 214 & 214 & 214 & 214 \\
$R^{2}$ & 0.295 & 0.411 & 0.309 & 0.470 \\
\hline
\end{tabular}

Notes: Data come from China's National Fixed-point Survey and the Village Democracy Survey. An observation is a village. In all columns, the dependent variable is the number of land takings in the village. The standard set of controls, $X_{i}$, is controlled in all columns. (See Section V.C for the list of variables) Coefficients are reported with standard errors in parentheses. $*, * *, * * *$ respectively denotes significance at $10 \%, 5 \%$ and $1 \%$ level. 
Table 4: First Surname Village Head (VH) and Kinship Network(KN)

\begin{tabular}{lcccccc}
\hline \hline & \multicolumn{6}{c}{ Dep. Var.: Dummy of A Land Expropriation Happening } \\
\cline { 2 - 7 } & $(1)$ & $(2)$ & $(3)$ & $(4)$ & $(5)$ & $(6)$ \\
\hline VH from 1st surname & 0.00476 & -0.00330 & -0.00411 & 0.00862 & 0.0270 & 0.0297 \\
& $(0.00694)$ & $(0.0113)$ & $(0.0113)$ & $(0.0125)$ & $(0.0255)$ & $(0.0254)$ \\
1st surname has KN & 0.00129 & & & -0.00772 & & \\
& $(0.00580)$ & & & $(0.0115)$ & & \\
1st-surname VH× 1st KN & -0.00140 & 0.00579 & 0.00535 & -0.00412 & -0.0248 & -0.0300 \\
& $(0.00954)$ & $(0.0142)$ & $(0.0143)$ & $(0.0174)$ & $(0.0320)$ & $(0.0317)$ \\
Other surnames have KN & -0.0102 & & & -0.00977 & & \\
& $(0.0101)$ & & & $(0.0225)$ & & \\
1st-surname VH $\times$ other KN & 0.0406 & 0.00330 & -0.0102 & 0.00545 & -0.0126 & -0.0236 \\
& $(0.0264)$ & $(0.0113)$ & $(0.0125)$ & $(0.0390)$ & $(0.0332)$ & $(0.0344)$ \\
Village FE & & yes & yes & & yes & yes \\
Year FE & & & yes & & yes \\
$X_{\text {it }}$ & & & & yes & yes & yes \\
\hline Observations & 5179 & 5179 & 5179 & 2270 & 2270 & 2270 \\
$R^{2}$ & 0.001 & 0.042 & 0.053 & 0.021 & 0.122 & 0.129 \\
\hline
\end{tabular}

Notes: Data come from China's National Fixed-point Survey and the Village Democracy Survey. An observation is a village and a year. In all columns, the dependent variable is a dummy indicating whether a land taking has occurred in the village-year. Columns (1) to (3) cover data from 1980 to 2008. $X_{i t}$, aset of additional controls, is controlled in columns (4) to (6). (See Section VI.C for the list of variables) Data for some of the variables in $X_{i t}$ are only available after 1993, which explains the smaller number of observations in columns (4) to (6). Coefficients are reported with standard errors in parentheses. $*, * *, * * *$ respectively denotes significance at $10 \%, 5 \%$ and $1 \%$ level. 
Table 5: 2nd Surname Village Head (VH) and Kinship Network(KN)

\begin{tabular}{|c|c|c|c|c|c|c|}
\hline & \multicolumn{6}{|c|}{ Dep. Var.: Dummy of A Land Expropriation Happening } \\
\hline & (1) & (2) & (3) & (4) & (5) & (6) \\
\hline \multirow[t]{2}{*}{ VH from 2nd surname } & 0.0102 & 0.0198 & $0.0262 * *$ & 0.0104 & 0.0116 & 0.0143 \\
\hline & $(0.00940)$ & $(0.0126)$ & $(0.0128)$ & $(0.0169)$ & $(0.0301)$ & $(0.0304)$ \\
\hline \multirow[t]{2}{*}{ 2nd surname has $\mathrm{KN}$} & 0.00451 & & & 0.000279 & & \\
\hline & $(0.00521)$ & & & $(0.0107)$ & & \\
\hline \multirow[t]{2}{*}{ 2nd-surname $\mathrm{VH} \times 2$ nd $\mathrm{KN}$} & -0.0220 & $-0.0283^{*}$ & $-0.0375^{* *}$ & -0.0347 & 0.00630 & 0.00307 \\
\hline & $(0.0138)$ & $(0.0159)$ & $(0.0166)$ & $(0.0244)$ & $(0.0392)$ & $(0.0403)$ \\
\hline \multirow[t]{2}{*}{ Other surnames have KN } & 0.0122 & & & 0.0155 & & \\
\hline & $(0.00903)$ & & & $(0.0164)$ & & \\
\hline \multirow[t]{2}{*}{ 2nd-surname $\mathrm{VH} \times$ other $\mathrm{KN}$} & $-0.0470 * * *$ & $-0.0366 * *$ & -0.0322 & $-0.0715 * * *$ & $-0.110 * * *$ & $-0.106 * * *$ \\
\hline & $(0.0126)$ & $(0.0166)$ & $(0.0198)$ & $(0.0246)$ & $(0.0341)$ & $(0.0338)$ \\
\hline Village FE & & yes & yes & & yes & yes \\
\hline Year FE & & & yes & & & yes \\
\hline$X_{i t}$ & & & & yes & yes & yes \\
\hline Observations & 5179 & 5179 & 5179 & 2270 & 2270 & 2270 \\
\hline$R^{2}$ & 0.001 & 0.043 & 0.054 & 0.022 & 0.122 & 0.129 \\
\hline
\end{tabular}

Notes: Data come from China's National Fixed-point Survey and the Village Democracy Survey. An obs-ervation is a village and a year. In all columns, the dependent variable is a dummy indicating whether a land taking has occurred in the village-year. Columns (1) to (3) cover data from 1980 to 2008. $X_{i t}$, a set of additional controls, is controlled in columns (4) to (6). (See Section VI.C for the list of variables) Data for some of the variables in $X_{i t}$ are only available after 1993, which explains the smaller number of observa-tions in columns (4) to (6). Coefficients are reported with standard errors in parentheses. *, **, *** respectively denotes significance at $10 \%, 5 \%$ and $1 \%$ level. 
Table 6: General Behavior of Village Heads

\begin{tabular}{lcccccc}
\hline \hline & \multicolumn{5}{c}{ Dep. Var.: Dummy of A Land Expropriation Happening } \\
\hline & $(1)$ & $(2)$ & $(3)$ & $(4)$ & $(5)$ & $(6)$ \\
\hline VH's surname has kinship & -0.000175 & -0.0247 & -0.0261 & -0.00382 & 0.0103 & 0.00711 \\
& $(0.00555)$ & $(0.0217)$ & $(0.0204)$ & $(0.0122)$ & $(0.0173)$ & $(0.0173)$ \\
Other surnames have kinship & 0.000780 & $-0.0511^{*}$ & $-0.0508^{*}$ & -0.0203 & -0.0201 & -0.0254 \\
& $(0.0161)$ & $(0.0287)$ & $(0.0289)$ & $(0.0276)$ & $(0.0476)$ & $(0.0435)$ \\
Village FE & & yes & yes & & yes & yes \\
Year FE & & & yes & & & yes \\
$X_{\text {it }}$ & & & & yes & yes & yes \\
\hline$\beta_{1}-\beta_{2}$ & -0.000955 & 0.0264 & 0.0246 & 0.0164 & 0.0305 & 0.0326 \\
& 0.0162 & 0.0188 & 0.0204 & 0.0259 & 0.0453 & 0.0421 \\
\hline Observations & 3464 & 3464 & 3464 & 1490 & 1490 & 1490 \\
$R^{2}$ & 0.000 & 0.053 & 0.066 & 0.021 & 0.164 & 0.175 \\
\hline
\end{tabular}

Notes: Data come from China's National Fixed-point Survey and the Village Democracy Survey. An observation is a village and a year. The sample includes only village-years in which the village head $(\mathrm{VH})$ has a surname that is one of the 4 largest surnames in the village. In all columns, the dependent variable is a dummy indicating whether a land taking has occurred in the village-year. Columns (1) to (3) cover data from 1980 to 2008. $X_{i t}$, a set of additional controls, is controlled in columns (4) to (6). (See Section VI.C for the list of variables) The data for some of the variables in $X_{i t}$ are only available after 1993, which explains the smaller number of observations in columns (4) to (6). Coefficients are reported with standard errors in parentheses. * , **, *** respectively denotes significance at $10 \%$, $5 \%$ and $1 \%$ level. 
Table 7: The Robustness of Network Effects Against Migration

\begin{tabular}{lccc|ccc}
\hline \hline & \multicolumn{6}{c}{ Dep. Var: No. of Land Expropriations } \\
\hline & $(1)$ & $(2)$ & $(3)$ & $(4)$ & $(5)$ & $(6)$ \\
\cline { 2 - 7 } & \multicolumn{7}{c}{ Neighborhood } & \multicolumn{3}{c}{ Islam } \\
\hline Kinship1 & -0.392 & $-0.521^{*}$ & $-0.570^{*}$ & -0.335 & $-0.450^{*}$ & $-0.511^{*}$ \\
Migrant workers (\%) & $(0.302)$ & $(0.300)$ & $(0.324)$ & $(0.309)$ & $(0.303)$ & $(0.325)$ \\
& 0.000721 & -0.00546 & 0.000338 & 0.00281 & -0.00327 & 0.00560 \\
Kinship1 $\%$ migrant & $(0.0115)$ & $(0.0113)$ & $(0.0127)$ & $(0.0112)$ & $(0.0109)$ & $(0.0120)$ \\
& 0.0241 & 0.0156 & 0.0115 & 0.0220 & 0.0134 & 0.0130 \\
Other network & $(0.0155)$ & $(0.0157)$ & $(0.0171)$ & $(0.0156)$ & $(0.0156)$ & $(0.0169)$ \\
& -0.0260 & -0.377 & -0.628 & -0.223 & -1.042 & 1.227 \\
Other network $\times \%$ migrant & $(0.423)$ & $(0.322)$ & $(0.374)$ & $(0.736)$ & $(0.745)$ & $(1.011)$ \\
& -0.000308 & 0.0184 & 0.0265 & 0.0895 & 0.139 & 0.110 \\
Province FE & $(0.0205)$ & $(0.0202)$ & $(0.0226)$ & $(0.0787)$ & $(0.0842)$ & $(0.0867)$ \\
$X_{i}$ & \multicolumn{7}{c}{} & yes & & yes \\
\hline$\beta_{3}-\beta_{4}$ & 0.0245 & -0.00281 & -0.150 & -0.0675 & -0.126 & -0.0973 \\
& 0.0269 & 0.0273 & 0.298 & 0.0830 & 0.0880 & 0.0906 \\
\hline Observations & 237 & 237 & 237 & 237 & 237 & 237 \\
$R^{2}$ & 0.023 & 0.273 & 0.374 & 0.035 & 0.280 & 0.398 \\
\hline
\end{tabular}

Notes: Data come from China's National Fixed-point Survey and the Village Democracy Survey. An observation is a village. In all columns, the dependent variable is the number of land takings in the village. The list of of variables in $X_{i}$ is listed in Section V.C. Coefficients are reported with standard errors in parentheses. $*, * *, * * *$ respectively denotes significance at $10 \%, 5 \%$ and $1 \%$ level. 


\section{References}

[1] Alesina, Alberto and Paula Guliano. "The Power of the Family." Journal of Economic Growth 15 (2010): 93-125.

[2] Alford, William P. “The Inscrutable Occidental: Roberto Unger's Uses and Abuses of the Chinese Past." Texas Law Review 64 (1986): 915-72.

[3] Alger, Ingela \& Jörgen W. Weibull. "Kinship, Incentives, and Evolution.” American Economic Review 100 (2010): 1727-1760.

[4] Ball, Richard. "Individualism, Collectivism, and Economic Development." Annals of the American Academy of Political and Social Science 573(1) (2001): 57-84.

[5] Bentolila, S. and A. Ichino. "Unemployment and Consumption Near and Far Away From the Mediterranean." Journal of Population Economics 21 (2008): 255-80.

[6] Bian, Yanjie. "Bringing Strong Ties Back In: Indirect Connection, Bridges, and Job Search in China." American Sociological Review 62 (1997):266-85.

[7] Buoye, Thomas. Manslaughter, Markets, and Moral Economy: Violent Disputes over Property Rights in Eighteenth-Century China. New York, NY: Cambridge Univ. Press, 2000.

[8] Burt, Ronald S. Structural Holes. Cambridge, Mass.: Harvard University Press, 1992.

[9] Burt, Ronald S. "Structural Holes versus Network Closure as Social Capital." In Social Capital: Theory and Research, edited by Nan Lin, Karen Cook, and Ronald Burt, 31-56. New York, NY: Aldine de Gruyter, 2001.

[10] Cai, Yongshun. 'Collective Ownership or Cadres' Ownership? The Non-agricultural Use of Farmland in China." China Quarterly 175 (2003): 662-680.

[11] Chan, Anita, Richard Madsen, and Jonathan Unger. Chen Village under Mao and Deng: Expanded and Updated Edition. Berkeley, CA: University of California Press, 1992.

[12] Chen, Quanrun. "Zhengfu wei zhifu buchangkuan zhengdi, guanyuan cheng kending bu kuidai baixing" ["Government takes land without full compensation, officials claim that they will definitely treat local residents fairly"]. Nanfang Nongcun Bao [Southern Rural News]: April 8, 2012. Available at http://news.sina.com.cn/s/201204-07/003924232248.shtml.

[13] Chen, Ruoying. Informal Sales of Rural Housing in China: Property, Privatization and Local Public Finance. Dissertation, University of Chicago, 2010, No. 3408511.

[14] Ch'u, Tung-tsu. Local Government in China under the Ch'ing. Cambridge, MA: Harvard University Press, 1962. 
[15] Cole, Daniel H. and Peter Z. Grossman. "The Meaning of Property Rights: Law versus Economics?" Land Economics 78 (2002): 317-30.

[16] Coleman, James S. The Foundations of Social Theory. Cambridge, MA: Harvard University Press, 1990.

[17] Cooter, Robert D. "Decentralized Law for a Complex Economy: The Structural Approach to Adjudicating the New Law Merchant." Univ. of Pennsylvania Law Review 144 (1996): 1643-1702.

[18] Curry, Oliver, Sam G.B. Roberts, and Robin I.M. Dunbar. "Altruism in social networks: Evidence for a 'kinship premium."' British Journal of Psychology 104 (2012): 283-95.

[19] de Soto, Hernando. The Mystery of Capital: Why Capitalism Triumphs in the West and Fails Everywhere Else. New York, NY: Basic Books, 2000

[20] Ding Jun. "Difang zhengfu chaobiao zhengdi wei youxiao kongzhi, Guotubu ni zaijin hongxian" ["Local land takings exceed predetermined boundaries, the National Land Bureau considers more tightening of quotas"]. 21 Century Economic News: Nov. 2, 2006. Available at http://news.sohu.com/20061102/n246167703.shtml.

[21] Durlauf, Steven N. \& Marcel Fafchamps. "Social Capital.” NBER Working Paper 10485 (May 2004).

[22] Ellickson, Robert C. Order Without Law: How Neighbors Settle Disputes. Cambridge, MA: Harvard Univ. Press, 1991.

[23] Ellickson, Robert C. “Property in Land.” Yale Law Journal 102 (1993): 1315-1408.

[24] Feng, Erkang. Shiba Shiji yilai Zhongguo Jiazu de Xiandai Zhuanxiang [The Modern Turn of Chinese Lineages since the 18th Century]. Shanghai, China: Shanghai People's Press, 2005.

[25] French, Howard W. "Protesters Say Police in China Killed Up to 20," New York Times: Dec. 10, 2005, at A1.

[26] Friedman, Edward, Paul Pickowicz and Mark Selden. Chinese Village, Socialist State. New Haven, CT: Yale University Press, 1991.

[27] Gambetta, A. The Sicilian Mafia. Oxford, UK: Oxford University Press (1990).

[28] Greif, Avner. "Family Structure, Institutions, and Growth: The Origins and Implications of Western Corporations." American Economic Review. 96 (2006): 308-316.

[29] Greif, Avner. Institutions and The Path to Economic Modernity: Lessons from Medieval Trade. Cambridge, MA: Cambridge University Press (2006).

[30] Guo, Xiaolin. "Land Expropriation and Rural Conflicts in China.” The China Quarterly 166 (2001): 422-439. 
[31] Habermas, Jürgen. The Postnational Constellation: Political Essays. Translated by Max Pensky. Cambridge, MA: MIT Press, 2001.

[32] Hayashi, Fumio. "Is the Japanese Extended Family Altruistically Linked? A Test Based on Engel Curves.” Journal of Political Economy 103 (1995): 661-74

[33] Ho, Samuel P. S. \& George C. S. Lin. "Emerging Land Markets in Rural and Urban China: Policies and Practices." The China Quarterly 175 (2003): 681-707.

[34] Hong Chaohui. “The Scarcity of Chinese Farmers' Land and Property Rights.” Modern China Studies 1 (2004): 56-65.

[35] Hsiao, Kung-Chuan. Rural China: Imperial Control in the Nineteenth Century. Seattle, WA: Univ. of Washington Press, 1960.

[36] Huang, Philip C. “'Public Sphere'/CCivil Society' in China.” Modern China 19 (1993): 216-40.

[37] Huang, Philip C. The Peasant Economy and Social Change in North China. Palo Alto, CA.: Stanford University Press, 1985.

[38] Huang, Philip C. The Peasant Family and Rural Development in the Yangzi Delta, 1350-1988. Palo Alto, CA: Stanford University Press, 1990.

[39] Inoue Tohru. Zhongguo de Zongzu yи Guojia Lizhi [China's Lineages and Ritual Institutions of the State]. Translated by Qian Hang. Shanghai, China: Shanghai Bookstore Press, 2008.

[40] Kam Wing Chan. "Internal Labor Migration in China: Trends, Geographical Distribution and Policies." Presentation for the United Nations Expert Group Meeting (Jan. 23, 2008). Available at http://www.un.org/esa/population/meetings/EGM_PopDist/Chan.pdf.

[41] Karra, Neri, Paul Tracey \& Nelson Phillips. "Altruism and Agency in the Family Firm: Exploring the Role of Family, Kinship, and Ethnicity." Entrepreneurship Theory and Practice 30 (2006), 861-877.

[42] Knack, Stephen \& Philip Keefer. "Does Social Capital Have an Economic Payoff? A Cross-Country Investigation.” Quarterly Journal of Economics 112 (1997): $1251-88$.

[43] Knack, Stephen \& Philip Keefer. "Institutions and Economic Performance: CrossCountry Tests Using Alternative Institutional Measures.” Economics \& Politics 7 (1995): 207-27.

[44] Krier, James E. “The Tragedy of the Commons, Part Two." Harvard Journal of Law \& Public Policy 15 (1992): 325-48.

[45] Lake, Ronald La Due, and Robert Huckfeldt. "Social Capital, Social Networks, and Political Participation.” Political Psychology 19 (1998): 567-84. 
[46] La Porta, R., F. Lopez-de-Silanes, A. Shleifer, and R. Vishny. "Trust in Large Organizations." American Economic Review 87 (1997): 333-38.

[47] La Porta, Rafael, Lopez-De-Silanes, Florencio, Shleifer, Andrei, Vishny, Robert W. (1999). “The Quality of Government." Journal of Law, Economics and Organization 15 (1999): 222-279.

[48] Leider, Stephen, Markus M. Möbius, Tanya Rosenblat and Quoc-Anh Do. "Directed Altruism and Enforced Reciprocity in Social Networks." Quarterly Journal of Economics 124 (2009): 1815-1851.

[49] Lessig, Lawrence. “The New Chicago School.” Journal of Legal Studies 27 (1998): 661-91.

[50] Li, Shi \& Thomas Vendryes. "Land interests and land conflicts: An investigation of the determinants of local land institutions in rural China." Paper presented at the 2012 Chinese Economic Association Annual Conference.

[51] Li, Wenzhi \& Jiang Taixin. Zhongguo Zongfa Zongzu Zhi he Zutian Yizhuang [Lineage Institutions and Common Property in China]. Beijing, China: China Social Sciences Press, 2000.

[52] Licht, Amir N., et al. "Culture Rules: The Foundations of the Rule of Law and Other Norms of Governance.” Journal of Comparative Economics 35 (2007): 659-685.

[53] Lum, Thomas. "Social Unrest in China." Washington, DC: Congressional Research Service RL33416, 2006. Available at http://digitalcommons.ilr.cornell.edu/crs/19/.

[54] McAdams, Richard H. "Comment: Accounting for Norms." Wisconsin Law Review 1997: 625-38.

[55] McAdams, Richard H. "The Origin, Development, and Regulation of Norms." Michigan Law Review 96 (1997): 338-433.

[56] McClurg, Scott D. "Social Networks and Political Participation: The Role of Social Interaction in Explaining Political Participation." Political Research Quarterly 56 (2003): 44964.

[57] Minzner, Carl F. "Xinfang: An Alternative to Formal Chinese Legal Institutions." Stanford Journal of International Law 42 (2006): 103-195.

[58] Miquel, Gerard Padro, Nancy Qian \& Yang Yao. "Social Fragmentation, Public Goods and Elections: Evidence from China." Bureau for Research and Economic Analysis of Development Working Paper 366 (2012). Available at http://ipl.econ.duke.edu/bread/papers2.php.

[59] North, Douglass C. "Institutions and Credible Commitment." Journal of Institutional and Theoretical Economics 149 (1994): 11-23. 
[60] North, Douglass C. and Barry Weingast. "Constitution and Commitment: The Evolution of Institutional Governing Public Choice in Seventeenth-Century England." The Journal of Economic History 49 (1989): 803-832.

[61] North, Douglass and Robert P. Thomas. The Rise of the Western World: A New Economic History. Cambridge, MA: Cambridge University Press, 1973.

[62] Olson, Mancur. The Rise and Decline of Nations. New Haven, CT: Yale University Press, 1982.

[63] Ostrom, Elinor. "Social Capital: A Fad or Fundamental Concept?” In Social Capital: A Multifaceted Perspective, edited by P. Dasgupta and I. Seragilden, 172-214. Washington DC: World Bank, 2000.

[64] Peng, Yusheng. "Kinship Networks and Entrepreneurs in China's Transitional Economy." American Journal of Sociology 109 (2004): 1045-1074.

[65] Pils, Eva. "Land Disputes, Rights Assertion and Social Unrest: a Case from Sichuan.” Columbia Journal of Asian Law 19 (2006): 235-92.

[66] Pomeranz, Kenneth. The Great Divergence: China, Europe, and the Making of the Modern World Economy. Princeton, NJ: Princeton University Press, 2000.

[67] Pomeranz, Kenneth. The Making of a Hinterland: State, Society, and Economy in Inland North China, 1853-1937. Berkeley, CA: University of California Press, 1993.

[68] Posner, Eric A. Law and Social Norms. Cambridge, MA: Harvard Univ. Press, 2000.

[69] Prosterman, Roy L. "Presentation on rural land takings in China and the broader context of farmers' tenure security." Congressional-Executive Commission on China, June 21, 2004. Available at www.rdiland.org.

[70] Putnam, R., R. Leonardi and R. Nanetti. Making Democracy Work: Civic Traditions in Modern Italy. Princeton: Princeton University Press, 1993.

[71] Qian, Hang. Zhongguo Zongzu Zhidu Xintan [Exploring the Lineage System in China]. Hong Kong: Zhonghua Book Press, 1994.

[72] Ravallion, Martin and Shaohua Chen. "Understanding China’s (Uneven) Progress Against Poverty.” World Bank Policy Research Working Paper 3408 (2004).

[73] Reed, Bradly W. Talons and Teeth: County Clerks and Runners in the Qing Dynasty. Palo Alto, CA: Stanford Univ. Press, 2000.

[74] Rose, Carol M. "Property as Storytelling." Yale Journal of Law \& Humanities 2 (1990): 37-57.

[75] Ruskola, Teemu. "The East Asian Legal Tradition." In The Cambridge Companion to Comparative Law, edited by Mauro Bussani and Ugo Mattei, 257-80. Cambridge Univ. Press, 2012. 
[76] Schulze, W.S., Lubatkin, M.H., and Dino, R.N. "Toward a theory of agency and altruism in family firms." Journal of Business Venturing 18 (2003): 473-491.

[77] Scott, James C. Weapons of the Weak: Everyday Forms of Peasant Resistance. New Haven, CT: Yale University Press, 1985.

[78] Siegel, David A. "Social Networks and Collective Action." American Journal of Political Science 53 (2009): 122-38.

[79] Su, Hong \& Kam Wing Chan. "Land Expropriation and Local Government Behavior." Hong Kong Baptist University, The Centre for China Urban and Regional Studies, Occasional Paper No.58 (2005).

[80] Sunstein, Cass R. "Social Norms and Social Roles." Columbia Law Review 96 (1996): 903-68.

[81] Thurston, Anne. Congressional Executive Commission on China, Roundtable Discussion on Village Democracy in China, Testimony of Anne Thurston, July 8, 2002. Available at http://www.cecc.gov/pages/roundtables/070802/thurston.php.

[82] Tsai, Lily. "Solidary Groups, Informal Accountability, and Local Public Goods Provision in Rural China.” American Political Science Review 101 (2007): 355-372.

[83] Wang Huning. Dangdai Zhonguo Cunluo Jiazu Wenhua [Lineage Culture in Contemporary China]. Shanghai: Shanghai People's Press, 1991.

[84] Washburn, Valerie Jaffee. "Regular Takings or Regulatory Takings? Land Expropriation in Rural China.” Pacific Rim Law \& Policy Journal 20 (2011): 71-124.

[85] Wen, Tiejun and Zhu Shouyin. "Xian yixia difang zhengfu ziben yuanshi jilei yu nongcun xiaochengzhen jianshe zhong de tudi wenti" ["Primitive capital accumulation of the sub-county governments and land issues under rural urbanization"]. Jingji Yanjiu Ziliao [Economic Research Materials] 1996(1): 2-25.

[86] Williamson, Claudia R. and Carrie B. Kerekes. "Securing Private Property: Formal versus Informal Institutions.” Journal of Law and Economics 54 (2011): 537-72.

[87] Woolcock, Michael. "Social Capital and Economic Development: Toward a Theoretical Synthesis and Policy Framework.” Theory and Society 27 (1998):151-208.

[88] Yang Shanhua. "Dangdai Zhongguo Jiazu Shili" ["Lineage Power in Contemporary China”]. Ningxia Social Sciences 18(6) (1999): 142-65.

[89] Yardley, Jim. "Farmers Being Moved Aside By China's Real Estate Boom." New York Times: Dec. 8, 2004, at A1.

[90] Yao, Shuntian. "Privilege and corruption: The problems of China's socialist market economy." American Journal of Economics and Sociology 6 (2002): 280-99. 
[91] Zhang, Jinjun. "Qingdai Jiangnan Zongzu zai Xiangcun Shehui Kongzhi zhong de Zuoyong" ["The Role of Lineages in Rural Governance in the Qing Lower Yangtze"]. Journal of Anhui Normal Univ. 34 (2006): 353-357.

[92] Zhang, Taisu (2012). "Social Hierarchies and the Formation of Customary Property Law in Pre-Industrial China and England." American Journal of Comparative Law 62 (2014): forthcoming.

[93] Zhang, Taisu (2009). "Zhongguoren zai Xingzheng Jiufen zhong Weihe Pianhao Xinfang" ["Why the Chinese Prefer Administrative Petitioning Over Litigation"]. Sociological Stud. 2009(3): 139-63.

[94] Zhao, Ling. "Rural Activism Seriously Changes: From Tax Disputes to Land Ownership." Southern Weekend: Sept. 2, 2004, at 5.

[95] Zheng, Zhenman. Family Lineage Organization and Social Change in Ming and Qing Fujian. Translated by Michael Szonyi. Honolulu, HI: Univ. of Hawai'i Press, 2000.

[96] Zhu, Keliang et al. "The Rural Land Question in China: Analysis and Recommendations Based on a Seventeen-Province Survey." New York University Journal of International Law \& Politics 38 (2006): 761-839.

[97] Zhu, Keliang \& Roy Prosterman. "Securing Land Rights for Chinese Farmers: A Leap Forward for Stability and Growth.” Yale Economic Review 5(2) (2009): 15-20. 